\title{
AS CONSEQUÊNCIAS SOCIAIS DO ROMPIMENTO DA BARRAGEM DE FUNDÃO EM MARIANA (MINAS GERAIS - BRASIL): UMA ANÁLISE POR MEIO \\ DE PESQUISA DE CAMPO
}

\section{THE SOCIAL CONSEQUENCES OF THE RUPTURE OF THE FUNDÃO DAM IN MARIANA (MINAS GERAIS - BRAZIL): AN ANALYSIS BY FIELD RESEARCH}

\author{
CAROLINA PAAZ \\ Advogada \\ Assessoria Jurídica Ambiental - Brasil \\ carolinapaaz@hotmail.com \\ LEONARDO DA ROCHA DE SOUZA \\ Professor Titular \\ Universidade Regional de Blumenau - Brasil \\ leorochasouza@gmail.com
}

RESUMO: Este artigo busca demonstrar as consequências sociais provenientes do rompimento da barragem de Fundão em Mariana (Minas Gerais - Brasil), com uma abordagem acerca da gravidade do desastre. Para isso, realizou-se uma pesquisa de campo com pessoas atingidas por aquele desastre ambiental, coletando-se dados por meio de um questionário, realizando-se uma pesquisa qualitativa com o método do estudo de caso. A pesquisa encontrou limitações práticas diante do receio de alguns atingidos em responder às questões, o que limitou o número de entrevistados. Como resultado, foi possível perceber a preponderância de interesses econômicos sobre os direitos humanos dos atingidos, com uma ampla reflexão das situações de vulnerabilidades e de injustiças ambientais. O diferencial deste artigo está no método utilizado, que permitiu verificar diretamente com os atingidos como eles perceberam a atuação da mineradora e como o desastre os afetou.

RESUM: Aquest article intenta mostrar les conseqüències socials de la ruptura de la presa de residus Fundão a Mariana (Minas Gerais, Brasil), amb una anàlisi de la [https://doi.org/10.17345/rcda2457] 
gravetat del desastre. Es va dur a terme un estudi de camp amb persones afectades per aquest desastre ambiental, incloent-hi dades recollides per mitjà d'un qüestionari, i una investigació qualitativa mitjançant un mètode d'estudi de casos. La recerca va topar amb limitacions pràctiques a causa del temor d'alguns afectats a respondre les preguntes, fet que va reduir el nombre d'entrevistats. Els resultats han permès percebre la preponderància dels interessos econòmics respecte als drets humans dels individus afectats, amb una reflexió general de les situacions de vulnerabilitat i d'injustícia ambiental. El factor diferencial d'aquest article rau en el mètode emprat, que ha permès comprovar directament, amb les persones afectades, la percepció de l'actuació de l'empresa minera i com l'accident va impactar la població.

RESUMEN: Este artículo intenta mostrar las consecuencias sociales de la rotura de la presa de residuos Fundão en Mariana (Minas Gerais, Brasil), con un análisis de la gravedad del desastre. Se ha efectuado un estudio de campo con personas afectadas por este desastre ambiental, incluyendo datos recogidos mediante un cuestionario, y una investigación cualitativa con un método de estudio de casos. La investigación encontró limitaciones prácticas debido al temor de algunos afectados a responder a las preguntas, lo que restringió el número de entrevistados. Los resultados han permitido percibir la preponderancia de los intereses económicos respecto a los derechos humanos de los individuos afectados, con una reflexión general de las situaciones de vulnerabilidad y de injusticia ambiental. El factor diferencial de este artículo radica en el método empleado, que ha permitido comprobar directamente, con las personas afectadas, la percepción de la actuación de la empresa minera y cómo el accidente impactó en la población.

ABSTRACT: This paper seeks to demonstrate the social consequences of the rupture of the Fundão dam in Mariana (Minas Gerais - Brazil), with an approach to the severity of the disaster. To do this, a field survey was carried out with people affected by this environmental disaster, with data collected through a questionnaire, and a qualitative research was carried out using the case study method. The research found practical limitations in the face of the fear of some affected in answering the questions, which limited the number of interviewees. As a result, it was possible to perceive the preponderance of economic interests to the human rights of those affected, with a broad reflection of situations of vulnerability and environmental 
injustices. The differential of this article is in the method used, which allowed to verify directly with those affected how they perceived the mining company's performance and how the disaster affected them.

PALAVRAS-CHAVE: Desastre ambiental - Deslocados Ambientais - Barragem de Fundão - Sustentabilidade Socioambiental.

PARAULES CLAU: desastre ambiental - desplaçament ambiental - presa Fundão - sostenibilitat socioambiental

PALABRAS CLAVE: desastre ambiental - desplazamiento ambiental - represa Fundão - sostenibilidad socioambiental

KEYWORDS: Environmental disaster - Environmental Displacement - Fundão dam - Socio-environmental Sustainability.

\section{INTRODUÇÃO}

Embora nos dias atuais se tenha muito mais consciência ambiental, percebese que grandes problemas ambientais ainda estão latentes. Prova disso foi o desastre ambiental que ocorreu no dia cinco de novembro de 2015, com rompimento da barragem de Fundão, da empresa Samarco Mineração S.A. (doravante Samarco), localizada no distrito de Bento Rodrigues, em Mariana, no Estado de Minas Gerais. A barragem, controlada pela empresa nacional Vale e pela empresa internacional BHP Billiton, continha rejeitos de minério de ferro que se esvaiu da barragem do Fundão pelo lado esquerdo e atingiu a barragem de Santarém. Todo conteúdo transbordou esta segunda barragem e deslocou-se em uma avalanche incontrolável de terra, lama e água pelo Rio Doce e em direção ao Oceano Atlântico.

Esse evento tem sido considerado o maior desastre ambiental do Brasil, com 19 (dezenove) vítimas fatais, centenas de animais mortos e uma mudança drástica na vida dos que foram afetados diretamente e indiretamente pelo mar de lama contaminado, além dos incalculáveis impactos ambientais da fauna e da flora. Além das mortes de pessoas e de animais, tais sedimentos arruinaram mais de 180 (cento e oitenta) edificações, arrastando automóveis, maquinários, semoventes, destruindo plantações, encobrindo logradouros e destruindo a história de vida de comunidades inteiras. A lama continuou deslocando-se, devastando os distritos e as localidades 
de Ponte do Gama, Paracatu de Cima, Paracatu de Baixo, Pedras, Camargos e Campinas, ultrapassando os limites da Comarca de Mariana, a ponto de afetar Gesteira e Barra Longa/MG, até atingir afluentes e subafluentes do Rio Doce. ${ }^{1}$

A amplitude desse desastre e a preocupação com suas consequências sociais foram os motivos para a realização desta pesquisa, centrada numa ampla reflexão de possíveis situações de vulnerabilidades e de injustiças ambientais ${ }^{2}$. A principal inquietação estava em buscar compreender o que acontece em uma localidade atingida por um desastre ambiental, analisando como são feitas as deliberações nas comunidades que recebem empreendimentos que geram um elevado risco para os seus moradores.

A pesquisa qualitativa ocorreu em um cenário natural, o que implicou no deslocamento do pesquisador ao local onde está o participante para conduzir a pesquisa, permitindo assim, um alto nível de detalhes sobre o local e as pessoas envolvidas, o que levou o pesquisador a um maior envolvimento com o objeto da pesquisa. Foram utilizando métodos múltiplos, interativos e humanísticos, realizando-se uma pesquisa qualitativa que buscou o envolvimento dos participantes na coleta de dados na tentativa de estabelecer credibilidade e harmonia com os entrevistados. Diversos aspectos podem surgir durante a realização de uma pesquisa qualitativa, o que a torna uma pesquisa emergente, ou seja, durante a realização da mesma uma variedade de novos aspectos poderá surgir, mudando o processo de coleta de dados. ${ }^{3}$

A opção por um estudo qualitativo, cujo delineamento se baseou na metodologia de estudo de caso, configurou-se como a mais acertada devido à necessidade de analisar a situação calamitosa nas comunidades atingidas pelo desastre, a qual permitiu a utilização de múltiplas fontes de evidência. Procurou-se identificar quais os reais problemas enfrentados pelos atingidos, como se dava a sua

\footnotetext{
1 Conforme informações contidas no processo cautelar n. ${ }^{\circ}$ 0400.15.003989-1. Cópia dos autos obtida diretamente no Fórum da Comarca de Mariana/MG.

2 Trabalha-se neste texto com a noção de justiça ambiental que resulta no "envolvimento significativo dos socialmente excluídos, tanto na elaboração como na aplicação de políticas públicas e normas ambientais. Também depende de buscar um tratamento justo dessa parcela da sociedade, o que significa que os mais pobres não devem suportar mais que outros as consequências negativas das decisões ambientais" (SOUZA, Leonardo da Rocha de. Democracia Deliberativa e Justiça Ambiental. Revista Internacional de Direito Ambiental, v. 8, p. 187-204, 2014, p. 192) A justiça ambiental pode ser definida, assim, como "o conjunto de princípios que asseguram que nenhum grupo de pessoas, sejam grupos étnicos, raciais ou de classe, suporte uma parcela desproporcional de degradação do espaço coletivo". (ACSELRAD, Henri; HERCULANO, Selene; PÁDUA, José Augusto. A justiça ambiental e a dinâmica das lutas socioambientais no Brasil - uma introdução. In: (orgs.) Justiça Ambiental e Cidadania. 2. ed. Rio de Janeiro: Relume Dumará, 2004, p. 9-20, p. 9-10.)
}

3 CRESWELL, John W. Projeto de Pesquisa: métodos qualitativo, quantitativo e misto. 2. ed. Porto Alegre: Artmed, 2007. 
participação nas tomadas de decisões antes e depois do desastre, e de que forma a atividade econômica atingiu os direitos humanos dos entrevistados.

Foram entrevistadas 15 pessoas, sendo 8 deslocados ambientais, 1 Coordenador do SINE, 2 Assistentes Sociais, 1 Promotor de Justiça e 2 moradores da cidade. A pesquisa foi realizada no período de uma semana, no mês de setembro de 2016, na cidade de Mariana/MG. Essa pesquisa de campo gerou material para alguns artigos. O recorte dado para o presente texto selecionará as respostas relacionadas às consequências sociais do mencionado desastre ambiental.

Para a realização da coleta de dados foi elaborado um roteiro com questões gerais, abertas e amplas, que se subdividiram em outras questões bem específicas, com perguntas sobre a vida antes do desastre e após. As perguntas serviram para guiar a pesquisa durante a entrevista, a qual foi gravada e transcrita, a fim de coletar dados e ter maior conhecimento sobre o tema abordado. Foram realizadas entrevistas aleatórias com os atingidos pela tragédia que aceitaram prestar informações e com pessoas do Município de Mariana/ MG. Antes da pesquisa de campo, a proposta foi submetida e aprovada pelo comitê ética de uma Instituição de Ensino Superior. Na presença dos entrevistados, antes da coleta de dados, o procedimento foi-Ihes explicado e cada um assinou o Termo de Consentimento Livre e Esclarecido (TCLE), de acordo com a Resolução 466/12 do Conselho Nacional de Saúde, em duas vias. Uma via ficou com o entrevistado e outra com o pesquisador.

O conteúdo das entrevistas permeia o presente artigo, que começa realizando uma abordagem da mineração e da exploração de recursos minerais como atividade econômica, enfatizando o relacionamento das mineradoras com as comunidades (2), passando-se à análise das consequências sociais do desastre de Mariana-MG (3).

\section{ATIVIDADE ECONÔMICA, EXPLORAÇÃO DE RECURSOS MINERAIS E O RELACIONAMENTO DAS MINERADORAS COM AS COMUNIDADES}

Em muitos países a riqueza mineral é responsável pela economia e representa uma parcela significativa das exportações. Percebe-se que quanto mais progresso socioeconômico, maior o consumo de bens minerais que garantirão as disponibilidades dos recursos que a sociedade precisa. ${ }^{4}$

\footnotetext{
4 STEIGLEDER, Annelise Monteiro. Responsabilidade civil ambiental: as dimensões do dano ambiental no direito brasileiro. Porto Alegre: Livraria do Advogado, 2004. p. 14-15.
} 
A matéria ambiental ainda tem um paradigma antropocêntrico/utilitarista em que a sensibilidade em relação ao mundo natural é reduzida e os demais bens naturais são convertidos em matérias-primas a serem utilizadas no processo de produção ou relegadas à condição de fonte de satisfação do senso estético e do lazer humano. O valor dos bens materiais passa por critérios do mercado e, como esse é incapaz de traduzir o valor ético desses elementos naturais, tal dimensão fica sem reparação. ${ }^{5}$

A grande maioria das operações de mineração usa metais, reagentes altamente tóxicos, cianeto e mercúrio devido a suas propriedades condutoras de liberação. O processo de mineração envolve uma produção enorme de resíduos, e a eliminação desses resíduos representa um enorme desafio pois as áreas de mineração são um dos problemas ambientais mais preocupantes de muitos países. A indústria da mineração é, provavelmente, a atividade antropogênica que produz os impactos mais profundos no ambiente, sendo responsável por uma completa desfiguração da paisagem, eliminação da vegetação e por expressivos impactos sobre o solo, a água e o ar. Seja qual for a forma de extração, seja ela superficial ou subterrânea, a mineração e o processamento do minério geram uma quantidade enorme de resíduos, que são depositados próximos às áreas de mineração. ${ }^{6}$

A degradação produzida pela mineração, em todas as suas fases, age de modo negativo na qualidade ambiental e, ao longo dos anos, o processo de poluição da atividade minerária tornou-se irreversível:

A mineração de lavra anual com métodos precários como foi praticada até a década de 50, oferecia poucos danos à natureza. Nas minas de poço, encosta, a seleção de carvão era feita no fundo das minas. Todo o entulho de pedra, pirita e barro ficava nas galerias das minas e só o carvão era retirado. Nas bocas das minas havia uma segunda escolha; porém os rejeitos significavam quantidades reduzidas frente ao volume dos rejeitos atuais. À medida que os métodos e técnicas de lavra foram se mecanizando, o processo de poluição ambiental tornou-se incontrolável e, pode-se assim dizer, irreversível. ${ }^{7}$

5 STEIGLEDER, Annelise Monteiro. Responsabilidade civil ambiental: as dimensões do dano ambiental no direito brasileiro. Porto Alegre: Livraria do Advogado, 2004. p. 14-15.

6 OLIVEIRA FILHO, Luís Carlos Iuñes de. Análise de risco ecológica e mesofauna em áreas de mineração. Lages: [s.n.], 2013. p. 17.

7 CORRÊA, Jacson. Proteção ambiental e atividade minerária. Curitiba: Juruá, 2002. p. 39-40. 
O tráfego intenso de veículos pesados carregados de minério causam uma série de transtornos às comunidades que vivem no entorno da mineração, especialmente naqueles moradores que estão mais próximos. Um dos maiores transtornos sofridos pelos habitantes que moram no entorno de uma mineração, relaciona-se com a poeira, que pode ter origem tanto nos trabalhos de perfuração da rocha como nas etapas de beneficiamento e de transporte da produção. Esses resíduos podem ser solúveis ou particulares (que ficam em suspensão como lama e poeira). Outros impactos sentidos são a emissão de ruídos e a frequente deterioração do sistema viário da região. Para tentarem minimizar a grande degradação ambiental causada nas regiões onde é extraído o minério, as empresas mineradoras buscam realizar uma série de ações de sustentabilidade e de responsabilidade social. ${ }^{8}$

Acreditam que ao promover uma aproximação com as comunidades, através de ações filantrópicas, investimentos em projetos sociais, relacionamentos institucionais etc., poderiam fazer cessar ou mesmo antecipar-se aos conflitos socioambientais. As modificações nas formas de relacionamento da empresa para com as comunidades teriam o objetivo de neutralizar a crítica social e garantir o que no léxico corporativo vem sendo denominado de licença social para operar. $^{9}$

Ao criar mecanismos que assegurem o aumento do ritmo de exploração mineral, o Estado, ainda que em nome da geração de divisas que viabilizem políticas de redução da pobreza e desigualdade social, impulsiona um processo de despossessão (muitas vezes autoritária e violenta) dos grupos sociais nos territórios. ${ }^{10} \mathrm{~A}$ apropriação da natureza para fins meramente econômicos causa uma série de impactos nas comunidades que sobrevivem com os alimentos retirados da natureza e esses direitos precisam ser preservados:

El hábitat es el lugar en el que se construye y se define la territorialidad de una cultura, la espacialidad de una sociedad y de una civilización, donde se constituyen los sujetos sociales que diseñan e! espacio geográfico

\footnotetext{
8 CORRÊA, Jacson. Proteção ambiental e atividade minerária. Curitiba: Juruá, 2002. p. 22.

9 CORRÊA, Jacson. Proteção ambiental e atividade minerária. Curitiba: Juruá, 2002. p. 22.

10 MALERMA, Julianna; MILANEZ, Bruno. Um novo código mineral para quê? Le Monde Diplomatique Brasil, v. 6, n. 65, dez. 2012. p. 22.
} 
apropiándoselo, habitándolo con sus significaciones y prática, con sus sentidos y sensibilidades, con sus gustos y goces.

$[\ldots]$

Las condiciones de existência de las comunidades dependen de la legitimación de los derechos de propiedad sobre su patrimônio de recursos naturales, de sus derechos a preservar su indentidad étnica y su autonomia cultural, para redefinir sus processos de producción y sus estilos de vida. Em este sentido, lo nuevos derechos indígenas y ambientales van cuestionando y transformando la norma estabelecida por el sistema de ragulación jurídica de la sociedade, para dar cauce a nuevas demandas sociales y nuevas utopias. Las reinvidicaciones de los grupos indígenas, em sus luchas por la dignidade, la autonomia, la democracia, la participación y la autosugestión.... Ello nos leva a preguntarnos: de quién es la natureza? Quién otorga los derechos para poblar el planeta, para explotar la tierra y los recursos naturales, para contaminar el ambiente ${ }^{11}$

O município de Mariana, foco deste artigo, possui cerca de 58 mil habitantes e tem a sua economia dependente da extração de minério. Essa dependência da extração de minério, já trouxe, antes mesmo do desastre da barragem de Fundão, muitos problemas sociais, como manifestou um dos entrevistados:

Entrevista 9/10 (Assistente Social). Os moradores de Mariana passaram a precisar mais da assistência social, após o desastre? A cidade sempre teve problemas devido à mineração. O rompimento da barragem foi o ápice, sabe, porque a questão da mineração em si, ela já trazia diversos problemas pra Mariana, que, a gente só pode atinar com o rompimento da barragem. Por exemplo, a gente teve aqui a expansão da Samarco, chamado Projeto P4P. A Samarco, ela estava expandindo, então isso, o que acontece, trouxe trabalhadores da região inteira, então vieram muitos homens de fora e trabalharam aqui, com isso, o nosso comércio, ele inflaciona, as coisas ficam muito mais caras, o aluguel de uma casa em Mariana fica muito caro, porque as pessoas, ou elas trabalham com mineração, ou elas trabalham com isso, com o comércio e o aluguel. "Eu tenho uma casa lá que eu quero alugar", tipo isso, entendeu, então as pessoas vivem disso, aí, quando as pessoas vão embora, nós que dependemos muitas vezes de aluguel, do comércio, as coisas continuam caras, porque é cultural nosso cobrar um preço mais caro de aluguel,

11 LEFF, Enrique. Saber ambiental: sustentabilidad, racionalidad, complejidad, poder. Madrid: Siglo Veintiuno, 2001. p. 240, 69. 
ter um comércio mais caro, então, assim, a gente já sofria esses impactos pela mineração, é diferente de Ouro Preto, que é uma cidade muito próxima da gente, que vive do turismo, a gente não aprendeu a viver com outra coisa, a gente ainda não aprendeu, sabe, e uma das preocupações do nosso prefeito é justamente por isso, porque a empresa tinha um imposto pro Município, a gente não está contando com isso mais, então, assim, a gente está sofrendo por tudo isso.

A estreita ligação entre desenvolvimento econômico gerado pelo capitalismo e a consequente degradação ambiental, com diversos questionamentos de como compatibilizar o progresso e a qualidade de crescimento, ainda não resultou em medidas efetivas que consigam reduzir o consumo para que seja possível diminuir os danos ambientais. Pelo contrário, a cada ano o consumo de minério aumenta e existe cada vez mais a necessidade de se expandir as empresas mineradoras no mundo.

Após o derramamento da lama, ocasionado pelo rompimento da barragem de Fundão, constatou-se que os impactos sociais da tragédia são tão grandes quanto os impactos ambientais. Trata-se de tragédia que não é somente ambiental, ela é sobretudo humana, porque, conforme os dias vão passando, os atingidos são revitimizados, pois perderam tudo, inclusive o estilo de vida pacífico de que desfrutavam na vida em comunidade e a tranquilidade que o convívio diário nas comunidades atingidas Ihes propiciava. Grande parte dos antigos, moradores de Bento Rodrigues, sequer receberam auxílio adequado das empresas responsáveis para recobrar seus documentos pessoais e necessitaram enfrentar filas para pegarem roupas doadas por terceiros que lhes pudessem servir e também tiveram que se submeter - mesmo os idosos e as pessoas com deficiência - a longas horas de espera para serem informados sobre as perspectivas de atendimento a direitos básicos, como moradia, alimentação e renda mínima para subsistência. ${ }^{12}$ Essas e outras consequências sociais do desastre serão tratadas no próximo tópico.

\section{AS CONSEQUÊNCIAS SOCIAIS DO DESASTRE: A ATIVIDADE ECONÔMICA DESRESPEITANDO DIREITOS HUMANOS}

\footnotetext{
12 Processo cautelar n. ${ }^{\circ}$ 0400.15.003989-1. Inquéritos Civis: 0400.15.000306-1 e 0400.15.000307-9. Classe: Ação Civil Pública. (Cópia aos autos do processo obtido no Fórum da Comarca de Mariana/MG).
} 
O Distrito de Bento Rodrigues, local onde a barragem se rompeu, foi totalmente devastado. Bento Rodrigues é um subdistrito de Santa Rita Durão, localizado no município mineiro de Mariana. Até 2015 cerca de 600 habitantes viviam no local e existiam cerca de 200 imóveis ocupados. Além de Bento Rodrigues, Paracatu, Pedras, Ponte do Gama, Camargos e Campinas também foram atingidas.

O desastre ${ }^{13}$ provocado pelo rompimento da barragem de Fundão fez com que comunidades inteiras fossem forçadas a deslocarem-se de seus povoados. Conforme constatado na pesquisa de campo, essas pessoas tinham uma vida pacata em pequenos distritos, trabalhavam na terra, conviviam com os animais e formavam com os vizinhos uma grande família. A economia local dos distritos atingidos era formada por pequenos agricultores que plantavam para a sua subsistência. Neste tópico, verificar-se-á como esse desastre atingiu diversos direitos humanos identificados como direitos sociais, abordando o desrespeito ao direito à moradia (3.1), o desfazimento de condições de pertencimento e a vulnerabilidade socioambiental (3.2), a perda da identidade e do sustento devido à ausência compulsória dos bens ambientais (3.3), a perda de condições mínimas de existência humana digna e a pluralidade de afetados (3.4) e o sofrimento dos atingidos em questões relacionadas ao preconceito e à mudança de hábitos (3.5).

\subsection{O desrespeito ao direito à moradia}

A Constituição Federal de 1988 (art. $6^{\circ}$ ) trouxe a moradia no rol dos direitos sociais. A proteção dada para a moradia ocorrer por ser, junto com outros direitos fundamentais como a saúde e a educação, um direito humano essencial à dignidade da pessoa humana ${ }^{14}$. Não se trata somente de um conceito que se refere à

\footnotetext{
13 A Organização das Nações Unidas (ONU) define "desastre" como "uma grave perturbação do funcionamento de uma sociedade, causando perdas humanas, materiais e ambientais que excedem a capacidade da sociedade afetada de lidar com o problema usando apenas seus próprios recursos. (DESASTRES naturais: conhecer para prevenir. São Paulo: Instituto Geológico, 2009.)

14 Trabalha-se a noção de dignidade da pessoa humana entendendo-a como formada por quatro eixos estruturantes: "da autonomia e da liberdade (destaque para os direitos de liberdade e a proibição - na acepção kantiana - de instrumentalização do ser humano, destituindo-o da sua condição de sujeito), da igualdade e do reconhecimento (abarcando a pretensão de igual respeito e consideração, ademais das proibições de discriminação e direito à inclusão), bem como da identidade pessoal e integridades física, psíquica e moral (aqui a ênfase está nos direitos de personalidade), ao que se somam (inclusive pela sua relevância para viabilizar as demais esferas) níveis adequados de proteção social, em especial a garantia de um mínimo existencial e, portanto, de um conjunto de direitos sociais, econômicos, culturais e ambientais." (SARLET, I. W.; SOARES, F. R. . Reflexões sobre a dignidade da pessoa humana como fundamento de postulações indenizatórias no direito do trabalho. Civilistica.com - Revista Eletrônica de Direito Civil, v. 6, p. 1-34, 2017, p. 6)
} 
propriedade, mas, sobretudo, de um direito que influencia diretamente a esfera moral dos cidadãos.

Internacionalmente, o direito à moradia é reconhecido como um direito social humano indispensável à composição de um mínimo existencial para uma vida digna. A moradia, associada à propriedade, é um dos pilares dos direitos humanos e fundamentais:

O direito de propriedade foi inserido na Declaração dos Direitos do Homem e do Cidadão de 1.789, no art. 17, como um direito fundamental e inviolável. E mais tarde, na Declaração Universal dos Direitos Humanos, de 1948, o art. XVII preceitua: 1 - Toda a pessoa tem direito à propriedade, individual e coletivamente. 2 - Ninguém será arbitrariamente privado de sua propriedade. ${ }^{15}$

Faz parte da própria natureza do homem ter um lar, pois nenhum ser vive sem um lugar. A moradia representa a própria dignidade humana e a dignidade deve ser a qualidade intrínseca do ser humano. ${ }^{16} \mathrm{~A}$ moradia de qualquer pessoa não se resume somente a paredes, não se trata apenas de um espaço físico, mas sim um lugar onde estão todos os bens preciosos da pessoa, até mesmo bens sentimentais. Conforme Bühring:

O cidadão aufere cômodo, almeja esse lugar, ou seja, um lugar que possa chamar e reconhecer como seu, que Ihe seja próprio, a fim de que possa estabelecer relação de identidade, firmando vínculos coletivos e afetivos. Como já advertia Aquino, "a Cidadania assume feição comunitária, ou seja, não tem cunho apenas individualista. Dessa forma, a "movimentação global e coletiva, na busca por um padrão ambiental de equilíbrio e harmonia, entre Homem e Natureza" e que corresponde ao fortalecimento de valores cívicos. ${ }^{17}$

A moradia representa a segurança que o cidadão tem de ter o seu lugar no mundo e a necessidade básica do indivíduo, enquanto ser humano, e do cidadão,

\footnotetext{
15 BÜHRING, Marcia Andrea. A efetiva função da propriedade: a socioambiental. Caxias do Sul: Educs, 2016. p. 17.

16 Segundo o art. 25 da Declaração Universal dos Direitos Humanos: "Todo ser humano tem direito a um padrão de vida capaz de assegurar-lhe, e a sua família, saúde e bem-estar, inclusive alimentação, vestuário, habitação, cuidados médicos e os serviços sociais indispensáveis, e direito à segurança em caso de desemprego, doença, invalidez, viuvez, velhice ou outros casos de perda dos meios de subsistência em circunstâncias fora de seu controle".

17 BÜHRING, Marcia Andrea. A efetiva função da propriedade: a socioambiental. Caxias do Sul: Educs, 2016. p. 35.
} 
enquanto ser social. O ser humano costuma buscar um lugar para viver em segurança e essa busca e esse desejo de viver bem é o que o direito denomina de busca da dignidade. Essas escolhas são naturais porque são antropológicas. ${ }^{18}$

Fazendo uma analogia do rompimento da barragem de Fundão, com os deslocamentos forçados para construção de barragens, percebe-se que os danos provocados pelo deslocamento compulsório de uma comunidade para outro local nunca são devidamente mensurados e reparados. ${ }^{19}$

No geral, os grupos humanos que têm pouca integração ao mundo "moderno" ocupam um território em que encontram os recursos que lhes falta, sem tanta necessidade de transformá-los. Por isso é possível compreender os valores intrínsecos que permeiam a vida e os anseios das pessoas que são cerceadas de continuar vivendo naquele lugar, no ambiente em que passaram toda a sua vida. ${ }^{20}$

Segundo autos do Inquérito Civil, o desastre de Mariana-MG violou frontalmente os direitos humanos dos atingidos, ferindo os direitos mais basilares:

Nota-se que a situação dos atingidos - cerca de 350 (trezentas e cinquenta) famílias vivendo em casas alheias às que residiam nos locais afetados, revela um direito individual homogêneo de caráter especial. Decerto, tal situação, causada e mantida pelas rés, afeta diretamente os grupos mais vulneráveis de atingidos, formados por idosos, crianças, deficientes e famílias numerosas (composta cinco ou mais pessoas). Trata-se, claramente, de uma violação coletiva de direitos humanos. ${ }^{21}$

Conforme se verifica da narração dos fatos, as pessoas atingidas encontravam-se em situação de extrema penúria. Estavam sem suas casas, sem a possibilidade de exercer suas atividades econômicas, faltando-Ihes itens de primeira necessidade, como por exemplo, roupas, papel higiênico, talheres etc. ${ }^{22}$

\footnotetext{
18 RECH, Adir Ubaldo; RECH, Adivandro. Cidade sustentável, direito urbanístico e ambiental: instrumentos de planejamento. Caxias do Sul: Educs, 2016, p.55

19 "Quem foi objeto de uma violência extrema, qualquer reparação nunca vai substituir aquilo que perdeu. Quem é expulso da terra onde morava há muitos anos - como no caso dos atingidos por barragens - sofre uma violência e uma desestruturação que pode gerar traumas [...]. Para reconstruírem sua identidade, essas pessoas precisam fazer o luto do que perderam." (BENINCÁ, Dirceu. Energia e cidadania: a luta dos atingidos por barragens. São Paulo: Cortez, 2011. p. 48.)

20 FERREIRA, Dallyla Taís Milhomem et al. Perdas simbólicas e os atingidos por barragens: o caso da Usina Hidrelétrica de Estreito, Brasil. Desenvolvimento e Meio Ambiente, v. 30, p. 73-87, jul. 2014.

21 Inquérito Civil: 0400.16.000071-9. Cópia dos autos obtida diretamente no Fórum da Comarca de Mariana/MG.

22 Processo cautelar n. ${ }^{\circ}$ 0400.15.003989-1. Inquéritos Civis: 0400.15.000306-1 e 0400.15.000307-9. Classe: Ação Civil Pública. (Cópia dos autos obtida diretamente no Fórum da Comarca de Mariana/MG.)
} 


\subsection{O desfazimento de condições de pertencimento e a vulnerabilidade socioambiental}

Além dos danos sofridos, os atingidos ficaram impedidos de exercerem suas atividades econômicas de sustento, por diversos motivos:

perda das ferramentas de trabalho; perda da área de pasto para o gado ou a perda do próprio gado; instabilidade residencial; desconfiança dos compradores dos produtos, por acreditarem que estão contaminados; dissolução das relações econômicas construídas durante os anos; instabilidade emocional e psicológica; necessidade de resolução de questões urgentes; perda dos documentos etc. ${ }^{23}$

Os problemas provocados por deslocamentos de comunidades causam desestruturação da mesma, causam rompimento de relações familiares e de grupos, e há um grande desenraizamento cultural com perda de vínculo espacial, doenças como depressão, malária, dengue, aumento da violência e até casos de suicídio. A inundação de espaços considerados sagrados, tais como florestas, cidades, escolas, cemitérios e igrejas, incidem de forma extremamente prejudicial sobre a vida dessas pessoas. ${ }^{24}$

Os desastres ambientais retratam vulnerabilidades e por esse motivo, tanto o impacto gerado quanto a magnitude dos desastres não devem ser medidos apenas pelo tipo de evento, sejam eles climatológicos, industriais ou híbridos, mas pela situação e grau de vulnerabilidade da localidade que sofre o impacto. Os impactos ambientais em áreas vulneráveis causam irreversibilidades de vidas e ecossistema e representa, dependendo da sua gravidade, a impossibilidade para as futuras gerações de fruição de um (bem) ambiental que é de uso comum. ${ }^{25}$

O conceito de vulnerabilidade, para o UNISDR (United Nations Office for Desaster Risk Reduction), é uma séria interrupção do funcionamento de uma comunidade ou de uma sociedade em qualquer escala devido a eventos perigosos que interagem com condições de exposição, vulnerabilidade e capacidade, levando a uma ou mais das seguintes perdas: humanas, materiais, econômicos e ambientais.

23 Processo cautelar n. ${ }^{\text {o } 0400.15 .003989-1 . ~ C o ́ p i a ~ d o s ~ a u t o s ~ o b t i d a ~ d i r e t a m e n t e ~ n o ~ F o ́ r u m ~ d a ~ C o m a r c a ~ d e ~}$ Mariana/MG.

24 BENINCÁ, Dirceu. Energia e cidadania: a luta dos atingidos por barragens. São Paulo: Cortez, 2011. p. 49 .

25 CARVALHO, Delton Winter de; DAMACENA, Fernanda Dalla Libera. Direito dos desastres. Porto Alegre: Livraria do Advogado, 2013.p.17 
O efeito do desastre pode ser imediato e localizado, mas geralmente é generalizado e pode durar um longo período de tempo. O efeito pode testar ou exceder a capacidade de uma comunidade ou sociedade para lidar com seus próprios recursos e, portanto, pode exigir assistência de fontes externas, que podem incluir jurisdições vizinhas, ou a nível nacional ou internacional. ${ }^{26}$

Os migrantes costumam ser pessoas muito vulneráveis, possuem inúmeras carências, pois falta-lhe o básico e o mais elementar para a própria sobrevivência, pois são obrigados a abandonar a sua cultura, os valores e o modo de vida, os laços familiares, como destaca Hannah Arendt:

A primeira perda que sofreram essas pessoas privadas de direito não foi a da proteção legal mas a perda dos seus lares, o que significava a perda de toda a textura social na qual haviam nascido e na qual haviam criado para si um lugar peculiar no mundo. Essa calamidade tem precedentes. ${ }^{27}$

As condições de vulnerabilidade resultam de processos sociais e mudanças ambientais resultando na vulnerabilidade socioambiental, com precariedade das condições de vida, de proteção social (trabalho, renda, saúde e educação, assim como aspectos ligados à infraestrutura, como habitações saudáveis e seguras, estradas e saneamento, por exemplo). As mudanças ambientais resultantes da degradação ambiental tornam determinadas áreas mais vulneráveis quando da ocorrência de uma ameaça e seus eventos subsequentes. ${ }^{28}$

A dignidade da pessoa humana é a qualidade intrínseca e distinta de cada ser humano que o faz merecedor do mesmo respeito e consideração por parte do Estado e da comunidade. Envolve um complexo de direitos e deveres fundamentais que assegurem a pessoa tanto contra todo e qualquer ato de cunho degradante e desumano, como venham a lhe garantir condições existenciais mínimas para uma vida saudável, além de propiciar e promover sua participação ativa ${ }^{29}$ e

26 NACIONES UNIDAS. Asamblea General. Informe del grupo de trabajo intergubernamental de expertos de composición abierta sobre los indicadores y la terminología relacionados con la reducción del riesgo de desastres. Septuagésimo primer período de sesiones, Tema 19 c) del programa Desarrollo sostenible: reducción del riesgo de desastres. Distr. general 1 de diciembre de 2016. Español. Original: inglés. Disponível em https://www.preventionweb.net/files/50683 oiewgreportspanish.pdf, acesso em 17/12/2018, p. 25

27 ARENDT, Hannah. Origens do totalitarismo. Tradução de Roberto Raposo. São Paulo: Companhia das Letras, 1989. p. 8.

28 FREITAS, Carlos Machado de et al. Vulnerabilidade socioambiental, redução de riscos de desastres e construção da resiliência: lições do terremoto no Haiti e das chuvas fortes na Região Serrana, Brasil. Ciência \& Saúde Coletiva, v. 17, n. 6, p. 1577-1586, 2012.

29 A ausência ou deficiência da participação ativa dos atingidos fica ainda mais saliente em conflitos ou desastres ambientais. "El conflicto ambiental pone en evidencia la ausencia de mecanismos estatales 
corresponsável nos destinos da própria existência e da vida em comunhão com os demais seres humanos. ${ }^{30}$

Hannah Arendt entendia que a privação da cidadania afeta substancialmente a condição humana, uma vez que o ser humano privado de suas qualidades - o seu estatuto político - vê-se privado de sua substância, vale dizer: tornado pura substância, perde a sua qualidade substancial:

A calamidade dos que não têm direitos não decorre do fato de terem sido privados da vida, da liberdade ou da procura da felicidade, nem da igualdade perante a lei ou da liberdade de opinião - fórmulas que se destinavam a resolver problemas dentro de certas comunidades - mas do fato de já não pertencerem a qualquer comunidade. Sua situação angustiante não resulta do fato de não serem iguais perante a lei, mas sim de não existirem mais leis para eles; não de serem oprimidos, mas de não haver ninguém mais que se interesse por eles, nem que seja para oprimi-los. Só no último estágio de um longo processo o seu direito à vida é ameaçado; só se permanecerem absolutamente "supérfluos", se não se puder encontrar ninguém para "reclamá-los", as suas vidas podem correr perigo. Os próprios nazistas começaram a sua exterminação dos judeus privando-os, primeiro, de toda condição legal (isto é, da condição de cidadãos de segunda classe) e separando-os do mundo para ajuntá-los em guetos e campos de concentração; e, antes de acionarem as câmaras de gás, haviam apalpado cuidadosamente o terreno e verificado, para sua satisfação, que nenhum país reclamava aquela gente. O importante é que se criou uma condição de completa privação de direitos antes que o direito à vida fosse ameaçado. $^{31}$

Os direitos sociais, de segunda dimensão (em oposição aos de $1^{a}$ geração, relacionados com a liberdade individual frente ao Estado), estão expressos na Constituição Federal, nos artigos $6^{\circ}$ ao 11 , no rol dos direitos fundamentais. Essa previsão atribuiu ao Estado a responsabilidade preponderante para a concretização

consolidados y extendidos para la escucha de la demanda social y del interés público em torno al ambiente. Por esta causa, el activismo verde emerge como forma de poner em tensión la debilidad o incluso la inexistencia de canales de participación y gestión participativa del ambiente, disputando tener voz y voto en este terreno fundamental de la vida pública." (MIRA, Julieta. Activismo verde. Participación ciudadana por el derecho al ambiente sano en la Argentina. Revista Catalana de Dret Ambiental, v. 7, n. 2, p. 1-42, 2016, p. 35)

30 STEINMTZ, Wilson. A vinculação dos particulares a direitos fundamentais. São Paulo: Malheiros, 2004. p. 117.

31 ARENDT, Hannah. Origens do totalitarismo. Tradução de Roberto Raposo. São Paulo: Companhia das Letras, 1989. p. 329. 
de um ideal de vida digno na sociedade, demandando atuações positivas por parte do Estado:

Os direitos sociais, como dimensão dos direitos fundamentais do homem, são prestações positivas proporcionadas pelo Estado, direta ou indiretamente, enunciadas em normas constitucionais, que possibilitam melhores condições de vida aos mais fracos, direitos que tendem a realizar a igualização de situações desiguais. São, portanto, direitos que se ligam ao direito de igualdade. ${ }^{32}$

Após o rompimento da barragem de Fundão, da Samarco, o Ministério Público de Minas Gerais atuou para garantir os direitos das vítimas do rompimento, instaurando o primeiro Inquérito Civil que viabilizou os direitos dos atingidos e, em caráter emergencial, tomou os primeiros depoimentos, inquirindo alguns atingidos pelo desastre. ${ }^{33}$

Segundo Guilherme de Sá Meneghin, Promotor de Justiça do Munícipio de Mariana, não há dúvidas de que a população atingida pela catástrofe perdeu tudo: suas casas, seus móveis, seus carros, suas plantações, seus documentos, sua tranquilidade, suas fontes de renda, sua vida comunitária, em suma, toda a sua dignidade humana, em outras palavras, por causa da irresponsabilidade da empresa causadora do dano, os atingidos ingressaram em uma classe especial de vulneráveis:

Pessoas afetadas por desastres socioambientais, sublinhe-se, vidas devastadas, porque não foram somente casas destruídas, carros perdidos, animais mortos ou plantações perdidas: as vítimas do rompimento da barragem da SAMARCO perderam, sobretudo, bens imateriais, como a vida comunitária, as suas lembranças, suas histórias, sua tranquilidade, seus amigos, ou seja, bens irreparáveis, enterrados na lama, por causa das atividades irresponsáveis das rés. ${ }^{34}$

O Distrito de Bento Rodrigues possuía diversas cachoeiras que eram pontos de encontro da comunidade, bem como igrejas, dentre elas a de São Bento,

32 SILVA, José Afonso da. Curso de direito constitucional positivo. 34. ed. rev e atual. São Paulo: Malheiros, 2011. p. 286.

33 Fonte direta, obtida por meio da $2^{\text {a }}$ Promotoria de Justiça da Comarca de Mariana.

34 Inquérito Civil n. ${ }^{\circ}$ 0400.15.000306-1. Cópia dos autos obtida diretamente no Fórum da Comarca de Mariana/MG. 
construída há mais de três séculos, que foi completamente soterrada. No Distrito também funcionava a Escola Municipal de Bento Rodrigues a qual também foi soterrada junto com os cadernos, fotos, livros e lembranças de todos os moradores da comunidade.

A felicidade em morar nas comunidades que foram atingidas pelo derramamento de lama foi constatada nas entrevistas com os deslocados ambientais, quando perguntados como era a vida na comunidade, antes da barragem se romper:

Entrevista 01 (atingido): Como era a sua vida antes de a barragem se romper? Era bom demais. Bom demais? Sim, Na roça era tudo bem tranquilo, bem sossegado. Vocês moravam na roça? Era. A sua vida era em Bento? É. Eu só vinha aqui em Mariana pra passear mesmo, a gente gostava de morar lá. E você gostava de vir só para passear ou você já teve vontade de morar aqui na cidade? Não tenho vontade de morar aqui não, só vinha aqui pra passear mesmo. Vocês se davam bem com os vizinhos, com os parentes, com os amigos? Sim. Todo mundo era chegado um com o outro, a gente conversava, todo mundo já era amigo, né? Eu conhecia todo mundo. $\mathbf{O}$ que vocês faziam depois do trabalho ou, no teu caso que era estudante, nos finais de semana pra se distrair? Jogava bola com as meninas, fazíamos quadrilha. Tinha o bar da Sandra. Bar? É, o Bar da Sandra, tinha festa, a Festa da Mercedes, era isso aí.

A tristeza pelas perdas dos lugares comunais, perda das suas casas, é sentida por todos os entrevistados, que mostram um profundo desapontamento com a vida longe das suas comunidades:

\footnotetext{
Entrevista 05 (atingido): Como era a sua vida antes da barragem se romper? Eu, convivia com todo mundo, todo pessoal de Bento, pois a gente ia pra quadra e jogava bola e tudo, se queria fazer alguma coisa, os vizinhos eram tudo perto, era rapidão, agora aqui, não, agora tá tudo longe, pra gente fazer as coisas, não tem como a gente deixar filho na casa de ninguém, e, lá, todo mundo era enturmado, todo mundo conhecia todo mundo. Tinha a igreja, a escola e a praça onde todo mundo se encontrava. Agora aqui acabou tudo isso.
} 
Para mostrar como as pessoas se sentiam felizes nas suas comunidades, é esclarecedor o depoimento da deslocada ambiental:

Entrevista 11 (atingido): Do que viviam, como é que era a vida de vocês antes do rompimento da barragem. Vocês viviam do campo? Primeiro, quando nós tava morando lá, lá era uma maravilha, nós tava no céu e não sabia, eu não trocava o tempo que nós tava morando lá em Paracatu por Mariana, nunca na minha vida, nunca, lá era um lugar maravilhoso, povo todo, todo mundo trabalhava, vivia, na pobreza, eu não nasci, todo mundo trabalhava, todo mundo tinha a sua casinha boa, todo mundo tinha as suas coisas, as coisas que tinha era uma pra outra, a gente vivia que era maravilha, nós vivia mesmo, cinquenta vezes do que aqui em Mariana, nada disso - "você quer uma casa aqui em Mariana em lugar de Paracatu?", - "eu não quero", porque lá, a vida era maravilhosa, com todo mundo, com toda dificuldade que lá tinha, a gente era feliz, graças a Deus! Não tenho como plantar mais nada. A gente plantou essas florzinhas aqui, mas não tem jeito, não, porque lá a gente tinha, aqui não tem como. Se você chegasse na porta lá de casa, quantas pessoas tirava retrato da porteira lá de casa, a casa tinha aquela lata (chora), já estava assim embaixo, assim, a varanda, no meio da varanda, desde lá, tudo tapado de lata de cima abaixo, assim, uma lataria pra dentro e pra fora, debaixo assim tinha um jardim só, de um lado e de outro da minha casa, eu deixava tudo enfeitado... o carro entrava na porta do meu filho... Nossa, pra gente aqui é difícil demais. Vocês se encontravam aonde? Olha, lá a gente se encontrava na igreja, tinha a quadra lá, que, de domingo, reunia todo mundo pra contar causo, os meninos iam jogar bola, dia de festa, todo mundo, tinha festa lá direto, era bom demais, lá na praça, tinha som, tudo, lá era bom demais, a gente não ficava sozinho, sempre, sempre tinha um na casa do outro, porque lá era vizinho, todo mundo conhecia todo mundo, quando a gente sentia falta de um, ia na casa do outro

O sentimento de que viviam satisfeitos nas suas comunidades se faz presente no decorrer dos relatos, bem como a saudade dos lugares de encontro. É o que é sintetizado na fala de um deslocado ambiental:

Entrevista 15 (deslocado ambiental): Como era a sua vida antes de a barragem se romper? A minha vida era tranquila. Tranquila? É, assim, (inaudível-ruídos e vozes ao fundo), terminou aí o tranquilo, né, lá, a minha rotina, eu ia trabalhar na associação, na parte da manhã, chegava em casa, ia 
arrumar almoço, colocar os menino pra escola. Na parte da tarde, eu ia e voltava pra trabalhar na associação, mas já era na parte da fábrica, assim, a minha vida era bem tranquila. $\mathbf{O}$ que vocês faziam depois do trabalho e finais de semana para se distrair? Olha, assim a gente gostava muito assim, no fim de tarde, no sábado ou no domingo, a gente ficava sentado, lá onde eu morava tinha uma pracinha, na porta da minha casa, a gente gostava muito de sentar, ficar conversando, a gente tomava refrigerante, os meninos ficavam brincando lá perto, porque tinha muita criança. Às vezes, até a gente mesmo brincava com eles de peteca, de bola. Aí outras pessoas que gostam de tomar uma cervejinha iam pra praça, tinha a praça. Todo mundo se encontrava na praça? Sim, a praça era o centro de encontro das pessoas. Era na Praça da Igreja São Bento de Barra da Santa. É uma igreja branca com azul que aparece nas fotografias? Isso. As pessoas ficavam lá, assim, para conversar mesmo. Tinha gente que gostava de jogar baralho, outras mesmo era só pra ficar conversando mesmo, coisa de interior.

Outros aspectos da vida em comunidade são enfatizados nas falas dos deslocados ambientais:

Entrevista 21 (deslocado ambiental): Como é que era a sua vida antes de a barragem se romper? A minha vida lá era boa, sabe? Eu gostava muito de pescada, toda vida gostei de andar no mato, toda minha vida foi mais no mato, o que eu vivi lá foi maravilhoso. Vocês se davam bem com vizinhos, parentes, amigos? Tudo, tinha amizade com todo mundo, o povo lá era mesma coisa que irmão um com o outro, era um lugar pequeno, era uma cidadezinha pequena, um arraial. Um ajudava o outro, muitas pessoas ajudava, que sempre tem... tem gente que não jeito. Onde que vocês se encontravam, depois do trabalho, o que vocês faziam no final de semana? Muitos ficavam, no final de semana, era uma cervejinha, outros joga baralho, outros pescando, igual eu gostava de pescar, jogar bola, bola de futebol, porque todo mundo já gosta mesmo.

Retrato do dia a dia, dos habitantes atingidos pelo rompimento da Barragem de Fundão, são percebidos em cada depoimento:

Entrevista 24 (deslocado ambiental): Como era a sua vida antes de a barragem se romper? A minha vida era boa, eu trabalhava, buscava as minhas lenhas, eu tinha a minha casa com fogãozinho de lenha, eu tinha serpentina, 
então a vida da gente era de roça mesmo, a gente vivia em roça, tinha as nossas galinhas, pato, horta, a gente tinha, tinha os pés de fruta, que a gente tinha no quintal, e a gente cuidava daquilo. Lá onde que eu morava era perto de Camargos, eu tinha as minhas faxinas que eu fazia lá em Camargos. E lá era muito bom, um lugar que tinha muita água. Agora nós vamos pra um lugar que a água lá, nós não temos córrego, lá nós tinha muita vertente, tinha o córrego, tinha lugar lá que as cachoeira era num córrego, que a gente passava numa ponte, que lá, a gente ia lavar roupa, torcer roupa.

Os deslocados das regiões atingidas, que agora precisam viver na cidade de Mariana, sofrem com o distanciamento que se estabeleceu entre parentes, dificuldade em plantar alimentos que eram cultivados em hortas grandes e variadas, além do temor em criar os filhos em um ambiente com mais pessoas desconhecidas e com menos segurança. Essa perda da dignidade humana, a dificuldade de adaptação em um novo lugar e a grande vulnerabilidade social que se instalou após o rompimento da barragem, está descrita na fala dos atingidos ao serem questionados sobre a mudança de vida:

Entrevista 05 (deslocado ambiental): Como está a sua vida agora? To muito triste. Mudou tudo. A gente convivia com todos, deixava os filhos com vó ou deixava na casa de vizinho. Agora é cada um na sua casa. Cadê os vizinho, cadê os parente? Nem saio mais de casa. Só pra ir pro psiquiatra. Antes era tudo pertinho, a gente saía na rua já tava a casa do vizinho, a casa do parente. Tá tudo mudado.

Entrevista 11 (deslocado ambiental): Como está a sua vida agora? A mamãe fica triste porque ela sente que agora precisa viver de esmola, depende dos outros. Tivemos que aceitar as doações, a gente tinha que pegar porque a gente não tinha como comprar. É, porque ela se sente assim, como ela não dependia de ninguém, a gente não dependia, de uma hora pra outra, a gente ficar dependendo de tudo, de comida, roupa, calçado, de remédio, tudo, tudo dos outros, porque nós ficamos sem nada e ficamos dependendo mesmo e nós vivemos de doação. Até pouco tempo, nós dava doação mesmo, agora é que acabou, né, que aí agora eles dão o salário, tudo direito, mas as roupas que a gente veste, tudo ainda é de doação, a gente ainda não comprou, que a gente pegou tudo de doação dos outros. Aqui ninguém se encontra, não, aqui tá todo mundo aqui em Mariana, mas só que cada um tá num lugar, num bairro, em 
outro lugar, eu mesma, só fui em três casa, só. Não voltei em casa de ninguém porque eu não sei a onde que tá. E lá em Paracatu, eu sabia onde tava todo mundo, eu ia na casa de todo mundo, aqui, não, aqui não tem como. Aqui eu só fui em três casa, que eu sei onde que tão, mas...

Entrevista 22 (deslocado ambiental): Como está a sua vida agora? A minha vida agora acabou, tá chato, você não esquece daquilo de jeito nenhum, porque a minha vida inteira foi lá, aqui eu tô sem destino, eu não sei o que eu faço, lá eu tinha o meu serviço, eu ganhava o meu dinheiro, eu mexia com a minha (inaudível), televisão, consertava moto dos outros, eu mexia com parte elétrica. $\mathrm{E}$ aqui eu não tenho nada disso, dentro da cidade grande aqui é muita concorrência, a pessoa tem que ter escola, tem que ter um dinheiro aqui, pra você fazer dinheiro, você tem que ter dinheiro, como é que eu vou montar um negócio aqui, sendo que eu não tenho um diploma?

Percebe-se nessas situações o que Caubet chama de violência física e de violência simbólica contra as populações vulneráveis, as quais são obrigadas a abandonar as suas terras, gerando, assim, insegurança aos titulares dos direitos reais de posse e de usufruto, com usurpação, confisco, esbulho, violência, entre outros abusos cometidos. Repete-se aqui os comportamentos antijurídicos e antissociais das autoridades de quase todos os países da União Europeia, situação que, em um momento da crise de emigrantes políticos e ambientais, confirma que os direitos e as normas que protegem os direitos humanos são aparentes. São milhares de pessoas que são privadas de toda a dignidade, ou de sua vida, por pura omissão das autoridades locais ou regionais. ${ }^{35}$

A perda dos objetos pessoais também causaram, segundo fala de uma entrevistada (uma profissional da assistência comunitária que trabalha diretamente com os deslocados ambientais), um grande sofrimento que jamais será compensado por dinheiro de indenização:

Entrevista 19 (assistente social). Eu acho assim, que as coisas vão só piorar, infelizmente. Pensa só, a lama destruiu muitas lembranças também. A lama pegou e destruiu o álbum de casamento de uma mulher que eu atendi, ela só chorava. Ela fala assim - "nossa, a lama levou até as minhas lembranças do meu marido", sabe, aí tem família que fala assim - "nossa, todas as minhas

35 CAUBET, Chistian G. Tratados internacionais, direitos fundamentais, humanos e difusos: os estados contra o bem viver de suas populações. Florianópolis: Insular, 2016. p. 70. 
lembranças viraram pó", aí, nossa, é muito, muito triste. Outro senhor chorava por causa da sanfona. Esse da sanfona é o que tá em São Paulo, que a filha dele acabou de ligar, que eu quero até saber se ele tá bem lá, porque ele quer voltar de tudo quanto é jeito. A sanfona ele tinha ganhado de quem? Era do pai dele, uma sanfona que ele guardava, era do pai dele, já tinha mais de cem anos. Ele fala assim - "nada vai pagar isso, nada vai pagar, não adianta a empresa me dar o dinheiro que valeria, mas nada vai pagar isso".

Conforme os autos da Ação Civil Pública, trata-se de uma devastação de vidas humanas:

\begin{abstract}
Sublinhe-se vidas devastadas, porque não foram somente casas destruídas, carros perdidos, animais mortos ou plantações perdidas: as vítimas do rompimento da barragem da SAMARCO perderam, sobretudo, bens imateriais, como a vida comunitária, as suas lembranças, suas histórias, sua tranquilidade, seus amigos, ou seja, bens irreparáveis, enterrados na lama, por causa das atividades irresponsáveis das rés. ${ }^{36}$
\end{abstract}

O sentimento de pertencimento e a existência de objetivos comuns são os alicerces para efetivar os elos entre os membros da comunidade, pois seria aquilo que mantém as pessoas unidas a despeito de todos os fatores que poderiam separá-las. ${ }^{37}$ A comunidade é associada à ideia de pertencimento. Na atualidade, 'não ter' uma comunidade significa 'não pertencer', estar desprotegido e fadado a viver uma vida de riscos e incertezas. ${ }^{38}$ Hannah Arendt defendia que a inserção de um ser humano em uma comunidade que lhe seja própria é requisito de sua humanidade. É justamente o fato de um ser humano pertencer a um grupo organizado que confere ao indivíduo a sua qualidade de ser humano. Diante disso urge a necessidade de manter os indivíduos dentro das suas comunidades que irão Ihe proteger e lhe respeitar. ${ }^{39}$

Analisando as mudanças bruscas na vida dos deslocados ambientais, antes e depois do desastre, os depoimentos emocionados retratam a dramaticidade das

\footnotetext{
36 Inquérito Civil nº 0400.15.000306-1 e 0400.15.000307-9.

37 LEANDRO, Janine Barreira. Comunidade: uma reflexão a partir de Zygmunt Bauman. Kairós, Revista Acadêmica da Prainha, v. 5, n. 1, jan./jun. 2008. p. 157.

38 SANTOS, Bruno Hermes de Oliveira. Um sonho de pertencimento: o fenômeno comunitário à luz do pensamento de Zygmunt Bauman. Revista Habitus: Revista da Graduação em Ciências Sociais do IFCS/UFRJ, Rio de Janeiro, v. 12, n. 2, p. 113-120, dez. 2014.

39 ARENDT, Hannah. Origens do totalitarismo. Tradução de Roberto Raposo. São Paulo: Companhia das Letras, 1989. p. 302.
} 
situações vivenciadas no cotidiano dessas vítimas, as quais relatam a falta do convívio com seus amigos e vizinhos:

Entrevista 01 (deslocado ambiental): Agora a gente vai falar da vida após o rompimento da barragem. Como está a sua vida agora? Esse pessoal de Bento mudaram muito, sabe, não conversam muito mais agora com a gente, quando vê na rua, não cumprimenta mais. Tem um monte de gente aí que é parente nossa, primo, primo irmão, sabe, assim, faz festa e agora nem convida, nem olha na nossa cara mais. Você sente que você está mais afastada dos amigos e da família, é isso? Tá todo mundo longe do outro, igual, a minha filha mora ali, o meu irmão aqui, o meu outro irmão lá. Como vocês se sentem em relação a tudo isso? Eu sonho muito com Bento, aí tem hora que dá até vontade de chorar, dá raiva não sei do que. A gente perdeu muita coisa. Os amigos não se enxergam mais. Eu tô indo num médico para melhorar a minha tristeza.

Entrevista 05 (deslocado ambiental): Como era a sua vida antes da barragem se romper? Eu, convivia com todo mundo, todo pessoal de Bento, pois a gente ia pra quadra e jogava bola e tudo, se queria fazer alguma coisa, os vizinhos era tudo perto, era rapidão, agora aqui, não, agora tá tudo longe, pra gente fazer as coisa, não tem como a gente deixar filho na casa de ninguém, e, lá, todo mundo era enturmado, todo mundo conhecia todo mundo. Tinha a igreja, a escola e a praça onde todo mundo se encontrava. Agora aqui acabou tudo isso. Como está a sua vida agora? (Inaudível). Tô muito triste. Mudou tudo. A gente convivia com todos, deixava os filhos com vó ou deixava na casa de vizinho. Agora é cada um na sua casa. Cadê os vizinho, cadê os parente? Nem saio mais de casa, só pra ir pro psiquiatra. Antes era tudo pertinho, a gente saía na rua já tava a casa do vizinho, a casa do parente. Tá tudo mudado.

Entrevista 11 (deslocado ambiental): Como era a relação entre os amigos, vizinhos, parentes? Ih, minha filha, nossa senhora, minha filha, se eu não tô aqui doente... Era bom demais, é o que eu mais eu sinto falta aqui em Mariana é isso, porque a gente ficou sozinho. Ô menina, eu vou te contar, se eu não tô aqui, igual eu tô aqui, Deus me livre, tem dez mês que nós estamos aqui, dez mês, eu entrei em depressão, eu tô tonta de tomar remédio, olha o que eu virei depois que eu tô aqui, hoje tá fazendo três dia que eu gripei, eu não tenho comigo, hoje que eu vim no médico, porque eu tava com muita febre, aí o médico mandou eu fazer uma injeção na veia pra corta a febre, a garganta 
inflamada, mas eu vou contar pra você, se eu tivesse lá em casa, a minha casa era cheia de gente... onde nós morava era vizinho pro todo lado, de um lado, do outro lado, na frente... eu enchia a minha casa de gente. Era bom demais. $\mathbf{E}$ aqui vocês estão se sentindo isolados? Aqui é, porque a gente ficou sozinho. A gente não conhece vizinhança... quem não conhece nós, não conhece, sabe, na cidade, nem todas pessoas gostam de um ir na casa do outro...

O relato dos sentimentos são particulares, porém, as situações relatadas, são comuns a todos os atingidos:

\section{Entrevista 24 (deslocado ambiental): E vocês encontram aqui outras pessoas, porque lá vocês tinham vizinhos, amigos que se encontravam e} aqui? Aqui é difícil, é só quando nós tiver o nosso reassento mesmo, porque aqui é só quando tem uma reunião que a gente encontra. Tem pessoas aqui que eu não sei nem onde que mora, então você não consegue encontrar tudo, dia de reunião, você chega e encontra, mas como que eu vou sair lá pro Rosário, lá pras Colina, ontem mesmo, eu fui na casa de uma cunhada minha, que ela é acamada, eu fui lá ver ela, lá na Colina, mas só ela mesma que eu fui, nas outras casas, eu não fui. Agora cada um está em um canto da cidade.

A tristeza na voz embargada é visivelmente percebida nas entrevistas e demostram que houve a quebra do vínculo comunitário entre os moradores das comunidades atingidas, haja vista que cada um dos moradores foi morar em uma casa diferente dentro do município de Mariana/MG, muitas vezes em bairros diferentes.

Percebe-se que o rompimento da barragem de Fundão afetou seriamente o desenvolvimento social das comunidades atingidas, pois os moradores sofrem pelo deslocamento forçado para a cidade de Mariana, sentem que sofrem discriminação, sentem falta dos bens que foram perdidos, a perda de documentos, das lembranças, sofrem danos psicológicos, preocupação com o futuro e a perda de acesso aos recursos comuns. Para os moradores das comunidades atingidas, foi negado 0 direito à autodeterminação ${ }^{40}$, ou seja, o direito de querer sair ou não da sua comunidade.

$40 \quad$ "A autodeterminação constitui, em síntese, o direito de liberdade do indivíduo, ou seja, o direito de definir seu projeto de vida, de se manifestar, de construir a sua personalidade e fazer suas escolhas sem interferências de terceiros ou do meio ao qual está inserido.” (MENEZES, Joyceane Bezerra de; MENDES, Vanessa Correia. O tratamento psiquiátrico e direitos humanos: uma análise dos instrumentos de controle da internação involuntária. Revista Jurídica Furb, v. 18, n. 35, p. 53-84, jan./abr. 2014, p. 65) 


\subsection{A perda da identidade e do sustento devido à ausência compulsória dos bens ambientais}

Conforme autos do Inquérito Civil, as pessoas atingidas pelo rompimento da barragem encontram-se em situação de extrema penúria e, se não bastassem os danos sofridos, as pessoas atingidas estão impedidas de exercerem suas atividades econômicas de sustento, por diversos motivos, citam-se alguns: perda das ferramentas de trabalho; perda da área de pasto para o gado ou a perda do próprio gado; instabilidade residencial; desconfiança dos compradores dos produtos, por acreditarem que estão contaminados; dissolução das relações econômicas construídas durante os anos; instabilidade emocional e psicológica; necessidade de resolução de questões urgentes; perda dos documentos etc. ${ }^{41}$

Em matéria jornalística daquele período tem-se acesso ao depoimento de uma lavradora que relata: o hábito de cultivar cebolinha, hortelã e pimentão enfrenta os problemas impostos pela falta de espaço e pelo abafamento produzido pela mistura de calor e concreto. Bem diferente da horta que ela plantava em Paracatu de Baixo, com couve, cebolinha, salsinha, pimenta, cenoura, beterraba, alface, além de outros vegetais e frutas. Hoje, a nova moradora da cidade de Mariana tenta plantar hortas em vasos, mas não consegue se acostumar com a nova realidade: "Eu passava o dia cuidando da horta e ajudando meu marido nas plantações da região. Hoje, fico em casa. Até o cachorro ficou triste." ${ }^{42}$

Os moradores dos distritos atingidos tinham uma ligação muito forte com a natureza que os cercava, a natureza estava no pátio de cada casa. $O$ homem constrói a sua identidade ao se integrar ao meio ambiente por meio de diferentes universos simbólicos, de forma que sua identidade se encontra intimamente ligada aos bens ambientais e aos seus valores enquanto indivíduo. ${ }^{43}$

Observa-se, a partir do relato de um deslocado ambiental entrevistado, um grande pesar nas falas dos atingidos pelas perdas dos bens ambientais:

\footnotetext{
41 Inquérito Civil: Inquérito Civil n. ${ }^{\circ}$ 0400.15.000306-1. Cópia dos autos obtida diretamente no Fórum da Comarca de Mariana/MG.

42 PARANAÍBA, Guilherme. Moradores de cidades atingidas por tragédia em Mariana não se adaptaram à nova realidade. 03 nov. 2016. Disponível em: $<$ http://www.em.com.br/app/noticia/gerais/2016/11/03/interna_gerais,820481/moradores-de-cidades-atingidaspor-tragedia-em-mariana-nao-se-adaptara.shtml> . Acesso em: 05 mar. 2017.

43 MENESTRINO, E. Povos tradicionais: do lugar ao não-lugar. Dissertação (Mestrado em Ciências do Ambiente) - Pós-Graduação em Ciências do Ambiente, Universidade Federal do Tocantins, Palmas, 2010.
} 
Entrevista 11 (deslocado ambiental). Não tenho como plantar mais nada. A gente plantou essas florzinhas aqui, mas não tem jeito, não, porque lá a gente tinha, aqui não tem como. Se você chegasse na porta lá de casa, quantas pessoas tirava retrato da porteira lá de casa, a casa tinha aquela lata (chora), já estava assim embaixo, assim, a varanda, no meio da varanda, desde lá, tudo tapado de lata de cima abaixo, assim, uma lataria pra dentro e pra fora, debaixo assim tinha um jardim só, de um lado e de outro da minha casa, eu deixava tudo enfeitado... o carro entrava na porta do meu filho... Nossa, pra gente aqui é difícil demais.

Ela molhava a horta que eu plantava, ela não pode mexer por causa da coluna, que ela tem problema de coluna, e eu plantava, ela levantava cedo e molhava a horta pra mim, ela catava de galinha, ela ia varrer terreiro, ela ia olhar uma flor, um trem e outro, ela tinha a rotina dela, e eu tinha a minha, aí, no caso, a gente nunca ficava parada, sempre tava mexendo, agora tem que ficar é parado, não tem como, é difícil demais. A gente andava na natureza. Era bom demais.

O pesar pela perda da identidade devido à ausência compulsória dos bens ambientais, revela-se na fala dos entrevistados:

Entrevista 21 (deslocado ambiental). A minha vida lá era boa, sabe? Eu gostava muito de pescada, toda vida gostei de andar no mato, toda minha vida foi mais no mato, o que eu vivi lá foi maravilhoso.

Eu falo assim, igual nós vivia, isso daí nunca mais, que lá onde nós morava lá tinha... tinha cinco cachoeira de água, nós tinha água pra tudo quanto é lado, tinha uma arvorezinha lá, que é onde nós pescava, onde que a gente ficava, que chamava Beiradinha, tinha o córrego do Ouro Fino, tinha o outro córrego da Juliana, que era muita água, tinha o do Camargos, que é o córrego do Camargos aqui de cima, que tinha muito peixe, então era uma região que nós pescava muito. Esse lugar lá eu gostava de pescar, eu pescava e tinha uns peixe "desse tamanho assim", Tilápia, eu gostava muito de pescar, ela não passa disso aqui, não, não passa disso, só que ela ficou (inaudível), você pega um peixe desse tamanho, dá quase tudo, então, eu ficava lá e enchia a sacola de peixe, lá acabou tudo, no dia, se eu tivesse lá, eu ia morrer, a gente não tinha como correr porque era pedra de um lado e de outro.

Entrevista 24 (deslocado ambiental). E lá era muito bom, um lugar que tinha muita água então aquele córrego, aquela água gostosa, aquela água com esse tempo de calor, aquela morninha, muito boa, era muito gostoso. A barragem era 
um lugar de encontro? É, era um lugar muito gostoso. Enquanto a gente torcia roupa tinha muito menino que brincava lá. Era uma maravilha. Lá no Bento, as mães tavam dentro de casa, e os filhos tavam lá indo pro lado da barragem, uma água muito bonita, e a meninada brincava todos os dias. A gente também se reunia na barragem para conversar. Os meninos passavam pra ir pra barragem pra brincar nesse poço, criança, adolescente, de nove anos, dez anos, ia nadar e brincar lá.

Percebe-se que as pessoas desprovidas de recursos socioeconômicos suportam um fardo dobrado de privações. O desenvolvimento humano deve envolver qualidade de vida, ou seja, uma vida longa e saudável, com acesso ao conhecimento e um padrão de vida descente. De acordo com o Programa das Nações Unidas para o Desenvolvimento, é indispensável um meio ambiente saudável para a sociedade, onde a saúde seja garantida e que o ar e a água sejam fontes de saúde. 44

O direito constitucional de todos ao meio ambiente economicamente equilibrado requer a não agressão da natureza em medida superior a sua capacidade de recuperação. ${ }^{45}$ Os efeitos da ação humana sobre o ambiente são sentidos, muitas vezes, de forma dramática, sem contar os inúmeros impactos materiais causados pela apropriação humana sobre o meio ambiente. Não há como mensurar o valor do patrimônio genético, da perda da beleza das paisagens ou do desaparecimento dos ecossistemas, das populações e modos de vidas tradicionais. ${ }^{46}$

Os danos ambientais expõem os direitos humanos ao perigo e é por esse motivo que a proteção ambiental é uma questão de necessidade básica. Essa relação entre direitos humanos e meio ambiente já foi reconhecida pela Corte Interamericana de Direitos Humanos, na Opinião Consultiva $n^{\circ} 23 / 17^{47}$, que aponta

44 PEREIRA, Agostinho Oli Koppe; CALGARO, Cleide. Os riscos ambientais advindos dos resíduos sólidos e o hiperconsumo: a minimização dos impactos ambientais através de políticas públicas. In: RESÍDUOS sólidos: consumo, sustentabilidade e riscos ambientais. Caxias do Sul: Plenum, 2014.p. 157, p. 163.

45 SILVEIRA, Clóvis Eduardo Malinverni. Risco ecológico abusivo: a tutela do patrimônio ambiental nos processos coletivos em face do risco socialmente intolerável. Caxias do Sul: EDUCS, 2014. p. 85.

46 SILVEIRA, Clóvis Eduardo Malinverni. Risco ecológico abusivo: a tutela do patrimônio ambiental nos processos coletivos em face do risco socialmente intolerável. Caxias do Sul: EDUCS, 2014. p. 85. p. 86.

$47 \quad$ Antes dessa Opinião Consultiva, a relação entre meio ambiente e direitos humanos vinha sendo reconhecida em casos específicos pela Corte Interamericana de Derechos Humanos. "Efectivamente, en los últimos años se ha avanzado mucho en relación con el reconocimiento por parte de la Corte Interamericana de Derechos Humanos del derecho a un medio ambiente sano como derecho humano. Los casos de graves violaciones de los derechos humanos por la construcción de grandes infraestructuras durante la década de 1990 están llegando actualmente a la Corte, que en los últimos años ha emitido sobre este tema cuatro sentencias y una medida cautelar, dos de ellas en el 2014. El primer caso de temática ambiental resuelto por la Corte 
para " la existencia de una relación innegable entre la protección del medio ambiente y la realización de otros derechos humanos, en tanto la degradación ambiental y los efectos adversos del cambio climático afectan el goce efectivo de losderechos humanos" e acrescenta:

El derecho humano a un medio ambiente sano se ha entendido como un derecho com connotaciones tanto individuales como colectivas. En su dimensión colectiva, el derecho a un medio ambiente sano constituye un interés universal, que se debe tanto a las generaciones presentes y futuras. Ahora bien, el derecho al medio ambiente sano también tiene una dimensión individual, en la medida en que su vulneración puede tener repercusiones directas o indirectas sobre las personas debido a su conexidad con otros derechos, tales como el derecho a la salud, la integridad personal o la vida, entre otros. La degradación del medio ambiente puede causar daños irreparables en los seres humanos, por lo cual un medio ambiente sano es un derecho fundamental para la existencia de la humanidad. 48

No mesmo sentido, Corte Internacional de Justiça se manifestou no caso Gabcikovo-Nagymaros, conforme voto do Juiz Weeramantry:

A proteção do meio ambiente é [...] uma parte vital da doutrina contemporânea dos direitos humanos, pois ela é condição sine qua non para numerosos direitos humanos, como por exemplo, o direito à saúde e o próprio direito à vida. Não há muita necessidade de aprofundar isso, já que o dano causado ao meio ambiente pode comprometer e minar todos os direitos humanos de que falam a Declaração Universal e outros instrumentos de direitos humanos. ${ }^{49}$

A dignidade é um direito inerente ao ser humano, irrenunciável da própria condição humana, e é função do Estado Democrático de Direito proteger os seus

Interamericana de Derechos Humanos fue el caso Mayagna (Sumo) Awas Tingni contra Nicaragua, planteado ante la Corte a finales de la década de 1990 y que se concluyó con una sentencia condenatoria emitida el 1 de febrero de 2000. Este caso giraba en torno a la concesión que el Estado nicaragüense había otorgado a la empresa Sol de Caribe, S. A., para explotar madera en el interior de tierras indígenas, sin consultar previamente a los miembros de la comunidad indígena (29 Corte IDH. Caso de la comunidad Mayagna (Sumo) Awas Tingni contra Nicaragua)" (PAMPLONA, Danielle Anne; ANNONI, Danielle. La protección del medio ambiente segundo el sistema interamericano de derechos humanos: socioambientalismo y el caso Belo Monte. Revista Catalana de Dret Ambiental, v. 7, n. 1, p. 1-27, 2016, p. 9)

48 CORTE INTERAMERICANA DE DERECHOS HUMANOS, Opinión Consultiva n. 23, de 15 de Noviembre de 2017, solicitada por la República de Colombia, disponível em http://www.corteidh.or.cr/docs/opiniones/seriea 23 esp.pdf, acesso em 16/12/2018, parágrafos 47 e 59. SEPARATE opinion of vice-president weeramantry. Disponível em: $<$ http://www.icj-cij.org/files/caserelated/92/092-19970925-JUD-01-03-EN.pdf>. Acesso em: 17 out. 2017. Tradução nossa. 
cidadãos. A dignidade da pessoa humana é o principal direito fundamental constitucionalmente garantido no sistema brasileiro. ${ }^{50}$ Percebe-se na fala da assistente social que trabalha diretamente com os atingidos o grande problema social causado pela afronta a esse direito constitucionalmente garantido:

Entrevista (assistente social - A): O pessoal que vivia nos distritos atingidos, muitos já eram vulneráveis. Eles já eram um pouco abandonados pelo poder público no geral. Mas aí, o que aconteceu, o desastre, ele aumentou, assim, ainda mais aquela vulnerabilidade daquelas pessoas, porque, antes, pelo menos, vamos supor, você era uma família simples, mas você tinha ali no seu canto uma couve pra comer, tipo assim, as pessoas ainda se viravam muito bem com aquilo que eles tinham, mas esse choque de eles ter vindo pra cidade foi muito grande, então isso já gerou outras questões sociais, começou violência, começou uso de álcool, uso de droga, coisa que eles não tinham tanto acesso assim, aqui na cidade já tiveram mais, então assim, até hoje é um baque muito grande de tudo que tá acontecendo pra eles, é uma mudança muito grande. A gente tá com um caso, assim, de uma família que tá meio que doente, lá em Paracatu, porque ainda vivem algumas pessoas lá, pra eles ainda é muito difícil aceitar vim pra cá, porque assim, o salário que a empresa paga, essas indenizações que a empresa paga, pra quem vive no distrito, é muito diferente, porque assim, antes eles não tinham que comprar uma verdura, agora, eles tendo que comprar uma verdura já é um gasto muito grande, antes, um salário pra quem mora no distrito é muito, não é que é muito, mas assim, é suficiente pra eles viveram tranquilos, aqui na cidade não é, então isso vai gerando, muitos, muitos, muitos problemas aqui na cidade.

Muitas comunidades, cuja produção econômica e sobrevivência dependem da dinâmica dos rios, como os ribeirinhos, são seriamente afetadas por decisões econômicas que na maioria das vezes não consideram as vidas humanas, pois comunidades inteiras são retiradas involuntariamente das terras que elas vivem. Isso faz com que as famílias percam completamente seu referencial cultural, de produção econômica e laços comunitários. Em 40 anos, mais de 1 milhão de pessoas foram deslocadas em razão da necessidade de geração de energia, segundo o Movimento dos Atingidos por Barragens (MAB) e em análise estatística, o relator do Banco

50 BUHRING, Marcia Andrea. A efetiva função da propriedade: a socioambiental. Caxias do Sul: Educs, 2016. p. 221. 
Mundial Michael Cernea diagnosticou, em 2004, o empobrecimento das populações deslocadas $^{51}$

\title{
3.4. A perda de condições mínimas de existência humana digna e a pluralidade de afetados
}

Há um direito às condições mínimas de existência humana digna que não pode ser objeto de intervenção do Estado e que ainda exige prestações estatais positivas. O Estado tem o dever de garantir que as condições de vida não sejam reduzidas, devendo concretizar sempre o mínimo existencial:

\begin{abstract}
A noção de mínimo existencial, compreendida, por sua vez, como abrangendo o conjunto de prestações materiais que asseguram a cada indivíduo uma vida com dignidade, no sentido de uma vida saudável, ou seja, de uma vida que corresponda a padrões qualitativos mínimos, nos revela que a dignidade da pessoa atua como diretriz jurídico-material tanto para a definição do núcleo essencial (embora não necessariamente em todos os casos e da mesma forma), quanto para a definição do que constitui a garantia do mínimo existencial, que, na esteira de farta doutrina, abrange bem mais do que a garantia da mera sobrevivência física, não podendo ser restringido, portanto, à noção de um mínimo vital ou a uma noção estritamente liberal de um mínimo suficiente para assegurar o exercício das liberdades fundamentais, ainda mais em se tratando de um cenário constitucional marcado - pelo menos no plano formal ${ }^{52}$
\end{abstract}

Deve ser feita uma reflexão sobre a conversão ecológica global, pois a destruição do ambiente humano é um fato muito grave, pois a vida dos seres humanos depende da natureza e deve ser protegida de várias formas de degradação. No entanto, qualquer pretensão de cuidar e melhorar o mundo requer

\footnotetext{
51 "Na lei não há, em princípio, nenhuma razão que autorize que um grupo, os que não querem o apagão, tenham prevalência sobre aqueles que sofrerão os impactos da construção de mais usinas. Um cálculo de felicidade com viés utilitarista, ou seja, que o resultado deva ser o bem-estar da maioria, está em desacordo com nosso projeto constitucional. A Constituição tem como um de seus fundamentos a cidadania e como objetivo a construção de uma sociedade justa e solidária. Não há solidariedade quando um grupo está segregado do desenvolvimento.”. (SACBIN, Flávia; ACCA, Thiago. Barrados na barragem: Nosso desejo de não ficar no escuro não justifica que milhares tenham direitos violados. O Estado de São Paulo, São Paulo, 28 fev. 2015. Disponível em: <http://alias.estadao.com.br/noticias/geral,barrados-na-barragem,1641594>. Acesso em: 28 jul. 2017.)

52 SARLET, Ingo Wolfgang. Notas sobre a assim designada proibição de retrocesso social no constitucionalismo latino-americano. Revista do TST, Brasília, v. 75, n. 3, p. 116-149, jul/set 2009.
} 
mudanças profundas nos estilos de vida, nos modelos de produção e de consumo, nas estruturas consolidadas de poder, que hoje regem as sociedades. ${ }^{53}$

O meio ambiente está presente nas questões mais vitais e elementares da condição humana, além de ser fundamental à sobrevivência do homem como espécie animal:

a vida e a saúde humana (ou como refere o caput do artigo 225 da Constituição Federal, conjugando tais valores à sadia qualidade de vida) só são possíveis, dentro dos padrões mínimos exigidos constitucionalmente para o desenvolvimento pleno da existência humana, num ambiente natural onde haja qualidade ambiental da água que se bebe, dos alimentos que se comem, do solo onde se planta, do ar que se respira, da paisagem que se vê, do patrimônio histórico e cultural que se contempla, do som que se escuta, entre outras manifestações da dimensão ambiental. ${ }^{54}$

Para reforçar a necessidade de proteger garantias constitucionais dos atingidos, o Ministério Público juntou nos autos da Ação Civil Pública, os relatórios que descreveram o grande contingente de crianças e adolescentes que ficaram vários dias sem aula. O Relatório da Prefeitura de Mariana e do Sistema Nacional de Proteção e Defesa Civil (SINPDEC) informa que são 3.875 (três mil, oitocentos, setenta e cinco) pessoas afetadas direta ou indiretamente, incluindo mortos, feridos, enfermos, desabrigados, desalojados, desaparecidos e outras hipóteses indiretas. $E$ as estruturas físicas destruídas, de acordo com relatório do Sistema Nacional de Proteção e Defesa Civil (SINPDEC), é de pelo menos 349 (trezentas e quarenta e nove) unidades habitacionais destruídas, 02 (duas) instalações de saúde destruídas, 04 (quatro) instalações de ensino destruídas, 11 (onze) instalações públicas de uso comunitário destruídas e 26 (vinte e seis) obras de infraestrutura pública destruídas, incluindo pontes e estradas. ${ }^{55}$

A lama não destruiu somente os distritos de Mariana. O Rio Doce, essencial para diversas regiões, com os seus mais de 850 quilômetros de extensão, também

53 IGREJA CATÓLICA. (Papa 2013-: Francisco). Carta Encíclica Laudato Si’: sobre o cuidado da casa comum. Disponível em: $\quad \underline{\text { http://w2.vatican.va/content/francesco/pt/encyclicals/documents/papa- }}$ francesco_20150524 enciclica-laudato-si.html>. Acesso em: 05 jul. 2017.

$54 \quad$ FENSTERSEIFER, Tiago. Direitos fundamentais e proteção do ambiente: a dimensão ecológica da dignidade humana no marco jurídico constitucional do estado socioambiental de direito. Porto Alegre: Livraria do Advogado, 2008. p. 61.

55 Processo n. ${ }^{\circ}$ 0400.15.004335-6. Inquéritos Civis: 0400.15.000306-1 e 0400.15.000307-9.Classe: Ação Civil Pública. Cópia dos autos obtida diretamente no Fórum da Comarca de Mariana/MG. 
foi contaminado pela lama da barragem de Fundão. A lama chegou à Usina de Aimorés, na divisa do Espírito Santo, atingindo em cheio tribos indígenas que dependem da água para sobreviverem. A tribo Krenak, um ramo dos botocudos, temido desde os tempos de colônia, foram em uma reunião com a Samarco pintados para a guerra. Uma caixa de papelão reunia o repasto: uma pilha de peixes inertes e fétidos recolhidos do Rio Doce, que atravessa a reserva indígena. Para beber, copos contendo uma água barrenta e imunda, extraída do mesmo leito fluvial: ${ }^{56}$

"Eles se assustaram e sentiram na pele o que nós estamos sentindo", diz Itamar Krenak, um dos 450 integrantes da aldeia, temeroso de que o Rio Doce jamais se recupere da devastação causada pelo tsunami lamacento. "O rio é nosso sangue, nossa religião, nosso sustento. Agora ele está envenenado, sem vida", afirma. ${ }^{57}$

Segundo a Declaração da ONU a respeito dos Povos Indígenas, o direito desses povos é ainda mais amplo, pois o direito ao meio ambiente vívido, seguro e sustentável é definido como parte da integridade cultural e do direito à autodeterminação. O direito à integridade ecológica combina elementos da integridade cultural e da autodeterminação e constitui, por conseguinte, a base para os direitos e deveres para com o meio ambiente. ${ }^{58}$

A contaminação do leito do Rio Doce acarretou incalculáveis danos para a agricultura, para pesca, para o turismo, para o setor industrial, para o transporte e o lazer das cidades que dependiam da água do Rio, e isso significa que os Direitos Humanos dessas pessoas também foram gravemente violados.

Faz-se necessário o repensar de uma nova ética em face dos problemas ambientais. Uma ética assimétrica, assumida em favor de partes mais fracas. $O$ peso dessa carga e seu caráter assimétrico podem ser relativizados quando se tem em conta o fim de que, se cada geração é devedora em relação às seguintes, ela é igualmente credora em relação às anteriores. ${ }^{59}$

56 LAMA de Mariana avança rumo ao mar e revolta população. Época, São Paulo, 19 nov. 2015. Disponível em: <http://epoca.globo.com/tempo/noticia/2015/11/lama-de-mariana-avanca-rumo-ao-mar-erevolta-populacao.html>. Acesso em: 02 out. 2017.

57 LAMA de Mariana avança rumo ao mar e revolta população. Época, São Paulo, 19 nov. 2015.

58 BOSSELMANN, Klaus. Direitos Humanos, meio ambiente e sustentabilidade. Revista do Centro de Estudos de Direito do Ordenamento, do Urbanismo e do Ambiente, n. 21, ano XI, 2008, p. 9-38, p. 20.

$59 \quad$ BARACHO JUNIOR, José Alfredo de Oliveira. Responsabilidade civil por dano ao meio ambiente. Belo Horizonte: Del Rey, 1999. p. 195. 
Para Ost, a humanidade não tem direito ao suicídio, existe uma obrigação do porvir, uma ética em relação ao futuro que nos compele a agir de forma que ainda hajam homens amanhã. Trata-se sobretudo de uma responsabilidade ontológica a respeito da ideia do homem - uma ideia de ser que implica o seu dever ser. ${ }^{60}$

Em relato emocionado, a assistente social entrevistada afirma que é difícil determinar quem são os atingidos, diante das grandes perdas para todos os envolvidos:

Entrevista 09 (assistente social): Bento foi totalmente destruído, agora, Paracatu, porque nós temos duas Paracatu, a De Baixo e a de Cima, logicamente, o de cima fica na parte mais alta, então ele não foi atingido, e o de Baixo, ele foi atingido indiretamente, claro, lá não tem mais como ter plantação, um dependia do outro, a questão de transporte, as estradas, então, atingidos, todos fomos, moradores do distrito e moradores da cidade também, bem como da região toda, na verdade, então assim, o que eu tenho observado, que, desde quando teve o rompimento, inicialmente, as pessoas, os moradores do distrito, elas foram diretamente atingidas, perderam casa, perderam família, perderam tudo, elas perderam tudo, e, assim, teve a emoção de tudo isso.

A partir dos autos da Ação Civil Pública $n^{\circ}$ 0400.15.000306, em casos como do rompimento da barragem de Fundão, considerando a quantidade de vítimas, direta ou indiretamente afetadas, houve dificuldade para classificar cada um dos afetados bem como considerar a complexidade de tratar os danos sofridos em caráter coletivo. $\mathrm{O}$ critério escolhido foi determinar como atingido:

Todo aquele que mantinha relação com as áreas afetadas e com os recursos naturais e/ou artificiais e culturais então disponíveis, por meio de relações econômicas (produção, comércio, agricultura, pecuária, pesca, subsistência, artesanato etc.), de trabalho (meeiros, parceiros, arrendatários, empregados rurais formais e informais etc.), comunitárias (vizinhança, parentesco, compadrio, relações de troca, solidariedade e sociabilidade etc.) e simbólicas ou culturais (igrejas, cemitérios, festas tradicionais, locais de culto e lazer etc.). ${ }^{61}$

60 OST, François. A natureza à margem da lei: a ecologia à prova do direito. Lisboa: Instituto Piaget, 1995. p. 319

61 Processo cautelar n. ${ }^{\circ}$ 0400.15.003989-1. Inquéritos Civis: 0400.15.000306-1 e 0400.15.000307-9. Cópia dos autos obtida diretamente no Fórum da Comarca de Mariana/MG. 
O depoimento do promotor de justiça, responsável pela Ação Civil Pública, explica em detalhes a dificuldade que foi enquadrar cada um dos atingidos, a fim de dimensionar o que cada um perdeu:

\section{Entrevista (promotor de justiça): Quantas pessoas foram atingidas} diretamente? É, vamos dizer que atingidos diretamente são aqueles que perderam a sua casa, são 1200 (mil e duzentas pessoas), uma estimativa de 1200 pessoas, uma pessoa que perdeu uma casa, uma propriedade imóvel, sendo que uma parte dessas pessoas que perderam a residência, elas não necessariamente estão morando numa casa da Samarco, porque, às vezes, elas tem uma outra residência onde elas moram, era uma residência de final de semana, era uma residência onde a pessoa tinha duplo domicílio, então, o número de pessoas que estão morando em casas alugadas não reflete necessariamente o número de pessoas que perderam a sua residência no local da tragédia. Diretamente seriam 1200 pessoas? Sim. Agora você tem contingente muito grande de pessoas que, eu não gosto muito de dizer direta ou indiretamente, sabe, porque veja bem a situação desse cidadão que eu vou te dizer, ele não perdeu a casa dele, ele não morava em Bento e nem Paracatu, ele morava em Camargos, ele trabalhava e morava numa casinha pequena nessa propriedade rural, essa propriedade rural foi toda destruída, menos a casa dele, o dono dessa propriedade rural evidentemente não tinha mais como pagar ele, não tinha mais como (inaudível) a remuneração dele e veio morar com a família em Mariana, e esse rapaz que era o trabalhador rural da propriedade, que ficou sem renda, mas ficou com casa, com tudo, ele não é atingido. [...] Dá pra colocar diretamente ou indiretamente, por isso que não dá, qual foi o direito afetado dele, o direito à renda, o direito à convivência comunitária, ele ficou isolado, então, eu gosto de falar atingido, nós podemos te dizer o grau de atingido ou direitos lesados, a pessoa que perdeu tudo, ela teve tudo lesado, ela tem o direito à moradia, à educação, à saúde, teve tudo lesado, ao lazer, tudo isso, todos direitos sociais que você tinha, você perdeu da noite pro dia. Já, agora, teve algumas pessoas que, por exemplo, é um terreno, ela não passou numa parte do terreno, mas consegue manter a sua atividade na outra parte do terreno, então ele foi afetado, ele perdeu uma parte da sua propriedade, que foi parcialmente afetada. Sim, mas perdeu vizinho, perdeu amigo, perdeu a igreja, perdeu áreas comunais todas, não é? Exatamente. Então é muito difícil, porque a empresa quer medir com a régua dela, o que ela acha que é bom pro atingido, não é esse o nosso princípio, o princípio do Ministério Público é tentar definir com eles o que é melhor pra eles. 
Com base na definição desenvolvida, restou o entendimento de que os atingidos são indivíduos, grupos ou comunidades que se enquadram em, ao menos, uma das seguintes situações (não foram considerados como atingidos somente quem perdeu a sua propriedade, o rol, neste caso, foi bem mais amplo):

I - Proprietário ou posseiro residente nos locais atingidos;

II - Proprietário ou posseiro não residente nos locais atingidos;

III - Morador, parceleiro ou meeiro, ocupante, inquilino, arrendatário, rendeiro, herdeiro, autônomo e trabalhador rural - não detentor da posse ou do domínio da terra, que morava e/ou produzia no imóvel, ou possuía benfeitorias, nos locais atingidos;

IV - Morador possuidor de qualquer bem material destruído ou danificado pelos eventos narrados nestes autos, incluindo veículos, roupas, eletrodomésticos, dinheiro e outros, atingidos pela lama;

V - Visitantes que perderam seus bens em decorrência da avalanche de lama, nos locais atingidos;

VI - Dependentes economicamente da terra e de recursos naturais, resultando na perda de acesso aos meios tradicionais de vida, incluindo a agricultura, a pesca, a pecuária, extração vegetal, dentre outros, nos locais atingidos pela lama;

VII - Residentes, comerciantes, empreendedores locais, artistas, produtores rurais que perderam seus meios de trabalho e/ou subsistência;

VIII - Indígenas, quilombolas e outras comunidades tradicionais, residentes de terras atingidas pela lama de rejeitos da mineração.

$[\ldots]$

A Constituição Brasileira veda o deslocamento de populações indígenas de suas terras, salvo, ad referendum do Congresso Nacional, em caso de catástrofe ou epidemia que ponha em risco sua população ou no interesse da soberania do país (artigo 231, $\S 5^{\circ}$ ).

Populações tradicionais não indígenas, como comunidades quilombolas, merecem tratamento análogo. Para estas comunidades étnicas, a identidade é baseada no território que ocupavam tradicionalmente. Nestes casos, de acordo com a Convenção 169 da Organização Internacional do Trabalho (OIT), que versa sobre os direitos dos povos indígenas e tribais, exige o "consentimento informado às medidas de reassentamento e compensação" (art. 16.1). Assim também, o Decreto 6.040, de 7/02/2007, que instituiu a Política Nacional de 
Desenvolvimento Sustentável dos Povos e Comunidades Tradicionais, fixa como objetivos [...]garantir os direitos dos povos e das comunidades tradicionais afetados diretamente ou indiretamente por projetos, obras e empreendimentos" (artigo 3, IV). ${ }^{62}$

Essa pluralidade de afetados pelo rompimento da barragem demonstra a amplitude desse desastre e dificuldade de mensurar suas consequências sociais e de definir quanto alguns direitos humanos foram desrespeitados pela atividade econômica em análise. Dentre as consequências sociais, restam ainda aquelas aqui reunidas como relacionadas ao sofrimento dos atingidos, analisadas no próximo tópico.

\subsection{O sofrimento dos atingidos: preconceito e mudança de hábitos}

O depoimento de outra assistente social entrevistada que atuou junto dos deslocados ambientais também é ilustrativo da problemática do deslocamento ambiental e as dificuldades de adaptação longe da comunidade de origem:

Entrevista 19 (assistente social): Começaram várias confusões, burburinhos, assim, primeiro era a comoção, depois começou meio que um preconceito, aí o que aconteceu, o desemprego foi aumentando com a crise, a cidade já não recebia mais a renda da empresa, tudo foi aumentando, então, as pessoas assim, da cidade, meio que começaram a culpabilizar os atingidos porque eles estavam achando que os atingidos estavam sendo privilegiados, porque a cidade tentou amenizar um pouco esse sofrimento, aí, assim, algumas coisas, algumas vagas do SINE eram pra essas pessoas, aí a população começou a ficar revoltada com aquilo, então, assim, nós começamos com esse trabalho do atendimento psicossocial desde 05 de janeiro [de 2016].

Os deslocados ambientais precisam lidar com uma carga muito alta de perdas: a perda de seu lugar de moradia, de suas relações sociais, da renda familiar, da falta dos bens ambientais, somados à revolta de alguns moradores da cidade de Mariana que se sentiram prejudicados após o rompimento da barragem, pois várias empresas terceiradas fecharam as suas portas e diversas pessoas

62 Processo cautelar n. ${ }^{\circ}$ 0400.15.003989-1. Inquéritos Civis: 0400.15.000306-1 e 0400.15.000307-9. Cópia dos autos obtida diretamente no Fórum da Comarca de Mariana/MG. 
responsáveis pelo sustento de suas famílias ficaram desempregadas. Isso tudo resultou em problemas sociais no município de Mariana, que agravou ainda mais a situação dos deslocados ambientais, segundo o comovente relato da assistente social:

Entrevista 19 (Assistente Social). Ouve casos de bullying na escola? Sim. Mas o bullying é muito por causa dessa questão, por exemplo, vamos supor, uma criança vê que o pai dele ficou desempregado depois que a barragem caiu, aí o filho, aquele outro filho que morava lá em Bento, o pai dele conseguiu um emprego porque ele foi atingido e a isso causa uma revolta. $O$ desastre representa o sofrimento de uma cidade num todo, entendeu? Porque foi um baque tão grande que todo mundo está sendo atingido, de um jeito ou de outro, a cidade inteira está sendo atingida. Por exemplo, um caso que a gente vê aqui muito no CRAS é garimpo. Garimpo é ilegal mas muitas famílias que viviam ao longo desse rio tiravam um pouco do sustento deles do garimpo, e essas famílias já eram famílias muito vulneráveis, atendidas pelo CRAS, mas muitos já tinham dado um tempo de pegar cesta, por exemplo, e estão voltando agora, porque não tem como eles garimparem, porque era o pouco do sustento que eles tinham. Fazendas que foram atingidas, que eram o que essas pessoas desses distritos ao entorno tinham pra trabalhar, não têm mais trabalho pra eles, entendeu? Então, o bullying acontece. Por exemplo, igual a uma escola que a gente tava uma vez, uma criança parece que falou assim, um discutindo com o outro e tal, aí o outro virou e falou assim - "ah, pelo menos eu não vim da lama", entendeu, aí ficam jogando umas piadinhas, uns pros outros, entendeu? Mas assim, a gente tem conversado muito, tem grupos nas escolas. O CRAS tem tentado desenvolver grupos, essas coisas assim, pra evitar isso.

Para completar o quadro das diversas mudanças enfrentadas pelos deslocados ambientais na cidade, a assistente social conta que até os hábitos que os deslocados ambientais tinham, de sentarem-se na frente das suas casas no final da tarde, nos distritos que eles viviam, também foram modificados na cidade, e isso também causou sofrimento:

Entrevista 19 (assistente social - B):Inclusive eu fiquei sabendo que o hábito que eles tinham no distrito de colocar cadeiras na rua, gerou problema aqui na cidade. É verdade? Sim. Na cidade tudo é muito diferente. Eu lembro que assim, logo quando a gente começou, a gente atendia o pessoal do Cabanas também, aí, 
tinha um senhor, que ele é muito diferente, porque antes, no distrito, eles ficavam sentados na rua, conversando com vizinho, ia ali no mercadinho, conversava com um e conversava com outro, aí ele falou pra gente um dia "gente, eu tô aqui perdido entre quatro paredes e uma televisão, porque eu não conheço ninguém", e ele tava começando com uma depressão, sabe, porque a vida dele depois do desastre era ficar trancafiado dentro daquelas quatro paredes e vendo televisão, então isso é uma mudança muito grande pra eles e eles não conseguem se adaptar, eles não tinham esse costume de ficar vendo televisão e ficar dentro de uma casa quadrada, eles tinham a onde ficar na horta deles, cuidando daquilo ali, o dia inteiro, então isso é um baque muito grande, agora, aqueles outros que tão no distrito, muitos até, a gente tem idoso, até que ligou agora, que a gente teve que pedir pra família vim buscar, de São Paulo, porque ele já morava sozinho, mas ele construiu, ele trabalhou a vida inteira em São Paulo, cidade grande, e ele construiu aquele lugarzinho pra ele lá em Bento, que ele conta, assim, pra viver o resto da vida dele ali, cuidando dos animais e tal, só que aí ele foi para o distrito - "eu tenho que continuar no distrito", ele tava amando, amando, já tinha feito amizade com o pessoal do distrito, todo mundo gostava dele, só que ele começou a ficar muito doente, e ele sozinho, tinha uns parentes assim que ajudavam e tudo mais, só que ele sozinho, não teve como, ele teve que voltar pra cidade mesmo, mas isso foi um baque muito grande pra ele, entendeu?

Esse mesmo problema também foi constatado, segundo a fala de outra entrevistada, que relatou os diversos problemas que surgiram após o deslocamento das populações atingidas para a cidade e alguns transtornos que surgiram com os vizinhos devido aos hábitos arraigados e ainda, o deslumbramento inicial de alguns deslocados ambientais ao receberem a primeira parcela de indenização, um montante antes nunca palpável:

Entrevista 9/10 (Assistente Social). O Bento era um distrito muito pequenininho, então as pessoas eram muito unidas, então, por exemplo, final de semana, todo final de semana mesmo, eles ficam sentados, eles têm o costume de ficar sentado na porta de rua, e eles estão em Mariana com essa mesma mania, então, assim, os vizinhos começaram a se incomodar com isso. Teve alguns que eram mais humildes, que quando receberam o dinheiro da indenização, ficaram deslumbrados com a questão financeira, então é um dinheiro que eles não tinham antes e passaram a ter, uma casa mobiliada, uma 
televisão de plasma, muitos não tinham isso, então acabou que começou a fazer churrasco, som alto, eu tive pessoas que vieram aqui reclamar comigo que queria tirar o vizinho de lá porque tava incomodando. Os comerciantes, quando as pessoas do Bento entravam nas lojas, já atendiam mal, inicialmente, porque até então, não tinham dinheiro, mas depois que começou a receber indenização da Samarco, teve uma loja em Mariana que ela vendeu 10 (dez) tablets para uma mulher que tem dez filhos, ela comprou, ela foi lá e comprou dez tablets. Então assim, a questão do comércio... Eles não souberam nem como gastar o dinheiro? Não, não souberam, teve compra de carro e capotamento... acabou que teve a questão mesmo de drogas, sabe, surtos, não sei se você vai ter tempo de procurar a saúde, a questão do CAPS, nós tivemos surtos, tanto aqui da cidade, pelo desemprego quanto por parte dos moradores diretamente atingidos, teve suicídio, aí eu estou falando não só a questão dos "impactados" direto, eu estou na questão da atual conjuntura mesmo, sabe, a gente teve caso de suicídio na cidade, depois desse desemprego.

Em tom de preocupação, o promotor entrevistado relata os problemas de rivalidade que surgiram, após os deslocados receberem alguns benefícios em virtude das ações que o Ministério Público ingressou contra a empresa poluidora:

\section{Entrevista (Promotor de Justiça): Eu conversei com bastante gente da} cidade, eu percebi que está tendo tipo uma rivalidade, assim, as pessoas de Mariana, por conta do desemprego, revoltadas porque os atingidos, para elas, estão sendo beneficiados. O senhor percebeu isso também? Claro, existe até um movimento aqui que é contrário aos atingidos, enfim, algumas pessoas, eu diria que até apesar de parecer que é grande, acho que não é a maioria da população não, sabe, mas existe um preconceito contra os moradores que foram atingidos. Isso causou um efeito perverso, de você... inicialmente a população estava muito compadecida com os atingidos. No início? No início, a partir do momento em que os atingidos passaram a ganhar certos direitos, em virtude das nossas ações aqui, evidentemente, eles passaram a ser vítimas de discriminação, por quê? Na cabeça de algumas pessoas, eles estão sendo beneficiados com a tragédia, isso é o que passa na cabeça de pessoas preconceituosas, mas, na verdade, nada do que a empresa tá fazendo, absolutamente nada, nada mais, nada menos do que é direito deles. Entendeu? Então isso é uma interpretação equivocada desenvolvida por pessoas, muitas 
vezes, de má fé, de mau caráter, então, a gente fica até preocupado com isso, inclusive eu instaurei um inquérito pra analisar...

Um morador da cidade, relata em seu depoimento, o seu ponto de vista, em tom de revolta, em relação aos deslocados ambientais, pois, segundo ele, muitos deslocados ambientais estão se aproveitando da situação:

\section{Entrevista 25 (morador da cidade e ex-funcionário da Samarco): Ah, a empresa antes do desastre não empregava as pessoas que viviam em} Bento Rodrigues e Paracatu? Não, na Vale eles não preenchem os requisito, não. O pessoal não é estudado, eles não têm nada pra poder trabalhar na Vale ou Samarco. O pessoal de Bento ou Paracatu, tem gente que não sabe nem assinar o nome, tão tudo ganhando um salário aí, tão tudo bonito, eu conheço eles todos, você precisa de ver, eles tão gordo, eles tão tudo gordo, pele fina, você entendeu, não, eles não trabalhavam não. Aí hoje a Samarco trouxe as empreiteira pra poder recuperar e falou assim: "os empregos, a prioridade pra turma de Bento e de Paracatu", você que vai lá, eles não vão, não, porque se eles vão e trabalham, eles perdem o que a Samarco tá pagando hoje. Eles condicionaram que enquanto não arrumasse emprego o emprego era delas. Você entendeu? Então, ao invés de eles correr e pegar as vaga pra eles, eles não vão, por que, por conta que se não eles perdem o que a Samarco tá pagando pra eles. E eles já como não gostavam, igual, tem uma cidade aí que passa no tal de Rio Doce, lá tinha uns peixe bom e tal, como eles não tão podendo pescar, porque a barragem não sei o que, tal e tal, inundou lá, matou os peixe, lá, se tinha meia dúzia de pescador, hoje, a turma de Rio Doce, que não conhece nenhum anzol, que não sabe nem por uma minha minhoca no anzol, declararam que são pescador pra poder ganhar. Tão gabando da Samarco, eu tô com dó da Samarco, eu não tenho um parente meu lá e tô orando e pedindo a Deus todo dia pra Samarco voltar a rodar, mas, se ela voltar a rodar, ela vai rodar pra esse povo aqui, enquanto que eles nunca vão largar essa "maminha", eles nunca, nunca mais vão largar essa "maminha" sossegado, você entendeu, eles tão aproveitando da situação. Eles tão aproveitando da situação. Passou, a enchente passou em algum terreno, matou lá um, dois bois, o cara falou que é cem bois. A Samarco não esperava, não ia fiscalizar quantos bois deles antes, que eles não sabiam que a barragem ia cair, você entendeu, "a minha casa tinha dez cômodo, assim, assim", 
Percebeu-se que o deslocamento causou uma série de incertezas em relação ao futuro, uma insatisfação com a vida atual, que afetou o bem-estar físico e mental dos atingidos, bem como agravou os problemas de depressão, ansiedade e problemas de saúde crônico dos atingidos:

Vê-se que a dimensão dos eventos, por si só, já é fator de risco e insegurança à garantia dos direitos das vítimas, já que a Samarco terá um enorme desafio diante de si: reparar o meio ambiente mineiro e capixaba e, principalmente, resgatar a dignidade dessas pessoas, diariamente vitimizadas pela ausência de moradia apropriada, trabalho, vida comunitária, lazer e outros direitos sociais. ${ }^{63}$

A tristeza e o luto pela perda de tudo que eles possuíam, fez com que a maioria dos deslocados ambientais procurassem ajuda psiquiátrica para conseguirem reconstruir as suas vidas:

Entrevista 01 (deslocada ambiental): Eu sonho muito com Bento, aí tem hora que dá até vontade de chorar, dá raiva não sei do que. Voz feminina-II: Ah, eu tô indo num médico porque eu choro muito.

Entrevista 11/12 (deslocada ambiental): Estou sempre no médico aqui. Ué porque foi um abalo triste, foi uma perca muito grande... além do mais, a gente, ninguém teve dó de nós, filha, quem teve dó de nós foi Deus, porque ninguém teve dó de nós, porque eu falo, falei, se a minha casa tivesse ficado, não fosse atingida, eu não saía, eu iria fazer uma sacola de tudo que eu tinha dentro de casa e mandar pros atingidos, mas não saía, não, porque graças a Deus, toda vida eu tive pra mim dar aos outros lá em Paracatu, pode perguntar, tem família que vem aqui me agradecer porque eu ajudei a criar a família deles. Trabalhando? Trabalhando. Chegavam lá em casa, eu tirava de tudo, fazia uma sacola, de cesta de comer - "leva, leva, comadre", - "toma, leva, fulano", pra não deixar os outros passar fome, eu criei família dos outros, graças a Deus.

\section{Entrevista 15 (deslocada ambiental): Como você se sente em relação a tudo} isso, em relação à saúde física, psíquica, alimentação? Surgiu algum problema de saúde com morador? Olha, muitos moradores estão indo em psicólogo, muitas pessoas que não tinha problema de saúde lá, hoje tem aqui, a

63 Processo cautelar n. ${ }^{\circ}$ 0400.15.003989-1.Inquéritos Civis: 0400.15.000306-1 e 0400.15.000307-9. Classe: Ação Civil Pública. Cópia dos autos obtida diretamente no Fórum da Comarca de Mariana/MG. 
minha mãe, acho que deu um bloqueio na cabeça dela, porque ela acha que ela não saiu de Bento, pra ela, ela tá em Bento ainda, sabe? Afetou a vida de todo mundo, foi assim, é raro o dia que a gente não dorme e acorda sonhando correndo de barragem, assim, é raro o dia que a gente não tem um pesadelo correndo d'água. É uma coisa assim que ficou gravada na cabeça, na mente, assim, da gente, que não saiu, foi uma cena muito triste.

Segundo o Ministério Público da cidade de Mariana/MG, os impactos sociais resultantes da catástrofe são geradores de direitos de restituição, compensação ou indenização. Sendo assim, conforme autos da Ação Civil Pública, o enquadramento para caracterizar quem são as pessoas atingidas decorrentes de seu deslocamento forçado/involuntário, foram assim descritos:

a) o deslocamento compulsório (de proprietários, não proprietários, moradores, produtores, comerciantes, ambulantes, dentre outros);

b) a perda da propriedade, da terra, da moradia e/ou de outros bens móveis e imóveis;

c) perda ou restrição de acesso a recursos e serviços básicos necessários à sobrevivência, tais como acesso à água potável, saúde, educação, moradia e alimentação;

d) perda ou redução de fontes de ocupação, renda ou meios de sustento;

e) perda de animais domésticos e/ou outros animais;

f) ruptura de circuitos econômicos, sociais, culturais e religiosos.

Devem ser consideradas como perdas as alterações impostas a circuitos e redes de sociabilidade, sempre que implicarem na ruptura de relações importantes para a reprodução social, consideradas as dimensões culturais e a identidade dos grupos, comunidades e famílias atingidas. As perdas de natureza afetiva, simbólica e cultural, imateriais e intangíveis, e por isso mesmo não passíveis de quantificação e, a fortiori, de monetarização, devem ser consideradas e objeto de ampla e aberta a discussão e negociação. ${ }^{64}$

O rompimento da barragem ocasionou uma grande mudança social e isso implica em considerar que há dimensões não estritamente pecuniárias ou materiais que terão que ser resolvidas na demanda, pois "há perdas que são resultantes da

64 Processo cautelar n. ${ }^{\circ}$ 0400.15.003989-1. Ação Civil Pública. Cópia dos autos obtida diretamente no Fórum da Comarca de Mariana/MG. 
própria desestruturação de relações prevalecentes, da eliminação de práticas, da perda de valores e recursos imateriais (religiosos, culturais)". 65

O desastre ambiental de Mariana ilustra bem a importância de se ter uma perspectiva multidisciplinar para tratar de temas tão complexos, pois o desastre provocado pelo rompimento da barragem de Fundão, pela sua dimensão, provocou diversos impactos que afetaram a vulnerabilidade das comunidades atingidas e a recuperação/reconstrução, pós-desastre, merecem atenção especial por parte do Judiciário, do Ministério Público e de agentes políticos, para que eles resguardem o direito das comunidades atingidas poderem voltar a ter uma vida normal.

\section{CONSIDERAÇÕES FINAIS}

Quando a barragem de rejeitos do Complexo minerário da Vale/Samarco rompeu e o seu conteúdo, carregado de resíduo de minérios, atingiu diversas comunidades brasileiras, destruiu e contaminou uma extensa área, causando danos ambientais e profundas mudanças na vida das comunidades atingidas. A lama da barragem retirou vidas humanas e de animais e enterrou sonhos e a dignidade das pessoas das comunidades atingidas, devido à perda do acesso aos tradicionais meios de vida, nesses incluindo a agricultura, a pesca, a pecuária, a extração vegetal, entre outros.

O deslocamento compulsório das comunidades os privou dos direitos fundamentais mais basilares, dentre eles a dignidade. Todos os atingidos perderam o direito de escolher se queriam ou não sair das suas casas, as crianças perderam o direito de permanecer nas suas escolas, os locais de encontros comunitários, como a igreja, a praça e a cachoeira, foram usurpados de maneira drástica e violenta. $O$ sentimento de isolamento também está presente na vida das pessoas que foram obrigadas a se deslocar, tendo em vista que era comum visitar os parentes e vizinhos, devido à proximidade das casas, o que hoje já não é mais tão usual, haja vista que os moradores dos distritos atingidos estão residindo em pontos diferentes da cidade.

Os deslocados ambientais também perderam o direito de permanecerem trabalhando nas suas atividades laborais, perderam a saúde, seus animais e terras que lhes garantiam suas subsistências, bem como perderam todos registros que

65 Processo cautelar n. ${ }^{\circ}$ 0400.15.003989-1. Ação Civil Pública. Cópia dos autos obtida diretamente no Fórum da Comarca de Mariana/MG. 
constituíam as memórias do passado, tais como fotografias, cartas, objetos de família. O trauma emocional e psicológico das pessoas que viviam nas comunidades atingidas é visível, pois eles foram forçados a modificar os seus estilos de vida, agora completamente diferente na cidade de Mariana.

Percebeu-se durante a execução da pesquisa, o conflito existente entre os moradores da cidade de Mariana e os deslocados ambientais, ora residentes da mesma, tendo em vista que uma grave crise econômica atingiu a todos devido à paralisação das atividades da Samarco. Houve impactos macroeconômicos e socioeconômicos após o desastre. Há necessidade de salvaguardar e proteger os deslocados ambientais e os atingidos indiretos, promovendo a integração de ambos pois todos os assentamentos são complexos e envolvem diversas ações sincronizadas. Os deslocados ambientais de Mariana devem ser vistos não como "problema" na cidade, mas sim como pessoas que podem contribuir com seu crescimento. As políticas de reassentamento devem estar inseridas na pauta da administração pública a fim de proteger os direitos humanos daqueles que serão permanentemente deslocados.

Qualquer reassentamento deve ter a participação ativa de todos os reassentados com a maior rapidez possível, pois quanto mais longo este reassentamento, maior o risco de geração de exclusão, pobreza e consequente degradação ambiental. Pode ocorrer ainda com os deslocados ambientais que se encontram em Mariana uma divisão intergeracional, ou seja, na época do reassentamento definitivo que está marcado para 2019, pode ser que muitos jovens, na época do reassentamento, não queiram sair da cidade de Mariana por já estarem adaptados.

Em relação aos idosos entrevistados, percebeu-se ainda uma maior dificuldade de adaptação à cidade de Mariana; são os que visivelmente mais sofrem. Muitos idosos que antes viviam sozinhos, agora necessitam residir com familiares e passaram, assim como todos os deslocados ambientais, a depender de ajuda financeira para sobreviver. Grande parte das famílias deslocadas retiravam suas subsistências da terra, antes produtiva.

A empresa responsável pelo desastre (além do Estado) precisa garantir os direitos dos deslocados ambientais, dentre eles: o direito à informação e participação, à assistência, à alimentação, à habitação, à saúde, direitos de personalidade, direito à educação e formação e direito ao trabalho. 
As injustiças socioambientais e as consequentes violações dos direitos humanos das populações atingidas precisam ser reparadas de forma exemplar para assegurar que tanto os órgãos públicos, quanto as empresas públicas e privadas, e até a sociedade como um todo, entendam a importância da preservação do meio ambiente, dos direitos humanos e que assim busquem caminhos e meios para a construção de normas e práticas que não só reparem as violações passadas mas que evitem que essas mesmas violações se repitam no futuro.

\section{BIBLIOGRAFIA}

ACSELRAD, Henri; HERCULANO, Selene; PÁDUA, José Augusto. A justiça ambiental e a dinâmica das lutas socioambientais no Brasil - uma introdução. In: . (orgs.) Justiça Ambiental e Cidadania. 2. ed. Rio de Janeiro: Relume Dumará, 2004, p. 9-20.

ARENDT, Hannah. Origens do totalitarismo. Trad. Roberto Raposo. São Paulo: Companhia das Letras, 1989.

BARACHO JUNIOR, José Alfredo de Oliveira. Responsabilidade civil por dano ao meio ambiente. Belo Horizonte: Del Rey, 1999.

BENINCÁ, Dirceu. Energia e cidadania: a luta dos atingidos por barragens. São Paulo: Cortez, 2011.

BOSSELMANN, Klaus. Direitos Humanos, meio ambiente e sustentabilidade.

Revista do Centro de Estudos de Direito do Ordenamento, do Urbanismo e do Ambiente. n. 21, ano XI, 2008, p. 9-38, Disponível em: <https://digitalisdsp.uc.pt/bitstream/10316.2/8821/3/1.pdf?ln=pt-pt p.20>. Acesso em: 17 out. 2017.

BÜHRING, Marcia Andrea. A efetiva função da propriedade: a socioambiental. Caxias do Sul: Educs, 2016.

CARVALHO, Delton Winter de; DAMACENA, Fernanda Dalla Libera. Direito dos desastres. Porto Alegre: Livraria do Advogado, 2013. 
CAUBET, Chistian G. Tratados internacionais, direitos fundamentais, humanos e difusos: os estados contra o bem viver de suas populações. Florianópolis: Insular, 2016.

CORREAA, Jacson. Proteção ambiental e atividade minerária. Curitiba: Juruá, 2002.

CORTE INTERAMERICANA DE DERECHOS HUMANOS, Opinión Consultiva $\mathbf{n}$.

23, de 15 de Noviembre de 2017, solicitada por la República de Colombia, disponível em http://www.corteidh.or.cr/docs/opiniones/seriea_23_esp.pdf, acesso em $16 / 12 / 2018$.

CRESWELL, John W. Projeto de Pesquisa: métodos qualitativo, quantitativo e misto. 2. ed. Porto Alegre: Artmed, 2007.

DECLARAÇÃO Universal dos Direitos Humanos. Disponível em: <https://www.unicef.org/brazil/pt/resources_10133.htm>. Acesso em: 03 de mar. 2017.

DESASTRES naturais: conhecer para prevenir. São Paulo: Instituto Geológico, 2009. Disponível em:

<http://www.igeologico.sp.gov.br/downloads/livros/DesastresNaturais.pdf>. Acesso em: 05 mar. 2017.

FENSTERSEIFER, Tiago. Direitos fundamentais e proteção do ambiente: a dimensão ecológica da dignidade humana no marco jurídico constitucional do estado socioambiental de direito. Porto Alegre: Livraria do Advogado, 2008.

FERREIRA, Dallyla Taís Milhomem et al. Perdas simbólicas e os atingidos por barragens: o casdo da Usina Hidrelétrica de Estreito, Brasil. Desenvolvimento e Meio Ambiente, v. 30, p. 73-87, jul. 2014. Disponível em:

<http://revistas.ufpr.br/made/article/view/34187>. Acesso em: 03 out. 2017.

FREITAS, Carlos Machado de et al. Vulnerabilidade socioambiental, redução de riscos de desastres e construção da resiliência: lições do terremoto no Haiti e das 
chuvas fortes na Região Serrana, Brasil. Ciência \& Saúde Coletiva, v. 17, n. 6, p. 1577-1586, 2012. Disponível em:

<http://www.scielo.br/pdf/csc/v17n6/v17n6a21.pdf>. Acesso em: 03 mar. 2017.

IGREJA CATÓLICA. (Papa Francisco). Carta Encíclica Laudatio Si': sobre o cuidado da casa comum. Disponível em:

<http://w2.vatican.va/content/francesco/pt/encyclicals/documents/papafrancesco 20150524 enciclica-laudato-si.html>. Acesso em: 05 jul. 2017.

LAMA de Mariana avança rumo ao mar e revolta população. Época, São Paulo, 19 nov. 2015. Disponível em: <http://epoca.globo.com/tempo/noticia/2015/11/lama-demariana-avanca-rumo-ao-mar-e-revolta-populacao.html>. Acesso em: 02 out. 2017.

LEANDRO, Janine Barreira. Comunidade: uma reflexão a partir de Zygmunt Bauman. Kairós, Revista Acadêmica da Prainha, v. 5, n. 1, jan./jun. 2008.

LEFF, Enrique. Saber ambiental: sustentabilidad, racionalidad, complejidad, poder. Madrid: Siglo Veintiuno, 2001.

MALERMA, Julianna; MILANEZ, Bruno. Um novo código mineral para quê? Le Monde Diplomatique Brasil, v. 6, n. 65, dez. 2012.

MENESTRINO, E. Povos tradicionais: do lugar ao não-lugar. Dissertação (Mestrado em Ciências do Ambiente) - Pós-Graduação em Ciências do Ambiente, Universidade Federal do Tocantins, Palmas, 2010.

MENEZES, Joyceane Bezerra de; MENDES, Vanessa Correia. O tratamento psiquiátrico e direitos humanos: uma análise dos instrumentos de controle da internação involuntária. Revista Jurídica Furb, v. 18, n. 35, p. 53-84, jan./abr. 2014.

MINAS GERAIS. Tribunal de Justiça de Minas Gerais. $2^{\mathrm{a}}$ Vara da Comarca de Mariana/MG. Processo $\mathbf{n}^{\circ}$ 0400.15.003989-1. Numeração única: 003989133.2015.8.13.0400. Classe: Cautelar. Requerente: Ministério Público do Estado de Minas Gerais. Requerido: Samarco Mineração S.A. Distribuição: 10/11/2015, disponível em https://bit.ly/2BpKFBv, acesso em 17/12/2018. 
MINAS GERAIS. Tribunal de Justiça de Minas Gerais. 2a Vara da Comarca de Mariana/MG. Processo $\mathbf{n}^{\circ}$ 0400.15.004335-6. Numeração única: 004335650.2015.8.13.0400. Classe: Ação Civil Pública. Autores: Ministério Público do Estado de Minas Gerais e Município de Mariana. Réus: Vale S.A., BHP Billiton Brasil Ltda., Samarco Mineração S.A. Distribuição: 10/12/2015, disponível em https://bit.ly/2QZiONr, acesso em 17/12/2018.

MIRA, Julieta. Activismo verde. Participación ciudadana por el derecho al ambiente sano en la Argentina. Revista Catalana de Dret Ambiental, v. 7, n. 2, p. 1-42, 2016

NACIONES UNIDAS. Asamblea General. Informe del grupo de trabajo intergubernamental de expertos de composición abierta sobre los indicadores y la terminología relacionados con la reducción del riesgo de desastres. Septuagésimo primer período de sesiones, Tema 19 c) del programa Desarrollo sostenible: reducción del riesgo de desastres. Distr. general 1 de diciembre de 2016. Español. Original: $\quad$ inglés. Disponível em https://www.preventionweb.net/files/50683 oiewgreportspanish.pdf, acesso em $17 / 12 / 2018$, p. 25

OLIVEIRA FILHO, Luís Carlos luñes de. Análise de risco ecológica e mesofauna em áreas de mineração. Lages: [s.n.], 2013.

OST, François. A natureza à margem da lei: a ecologia à prova do direito. Lisboa: Instituto Piaget, 1995.

PAMPLONA, Danielle Anne; ANNONI, Danielle. La protección del medio ambiente segundo el sistema interamericano de derechos humanos: socioambientalismo y el caso Belo Monte. Revista Catalana de Dret Ambiental, v. 7, n. 1, p. 1-27, 2016.

PARANAÍBA, Guilherme. Moradores de cidades atingidas por tragédia em Mariana não se adaptaram à nova realidade. 03 nov. 2016. Disponível em: https://bit.ly/2BvqkL4, acesso em 05/03/2017. 
PEREIRA, Agostinho Oli Koppe; CALGARO, Cleide. Os riscos ambientais advindos dos resíduos sólidos e o hiperconsumo: a minimização dos impactos ambientais através de políticas públicas. In: PEREIRA, Agostinho Oli Koppe; CALGARO, Cleide; HORN, Luiz Fernando Del Rio (org.). Resíduos sólidos: consumo, sustentabilidade e riscos ambientais. Caxias do Sul: Plenum, 2014.

RECH, Adir Ubaldo; RECH, Adivandro. Cidade sustentável, direito urbanístico e ambiental: instrumentos de planejamento. Caxias do Sul: Educs, 2016.

SACBIN, Flávia; ACCA, Thiago. Barrados na barragem: Nosso desejo de não ficar no escuro não justifica que milhares tenham direitos violados. O Estado de São Paulo, São Paulo, 28 fev. 2015. Disponível em:

<http://alias.estadao.com.br/noticias/geral,barrados-na-barragem,1641594>. Acesso em: 28 jul. 2017.

SANTOS, Bruno Hermes de Oliveira. Um sonho de pertencimento: o fenômeno comunitário à luz do pensamento de Zygmunt Bauman. Revista Habitus: Revista da Graduação em Ciências Sociais do IFCS/UFRJ, Rio de Janeiro, v. 12, n. 2, p. 113120, dez. 2014. Disponível em:

<https://Revistas.Ufrj.Br/Index.Php/Habitus/Article/Viewfile/11441/8391>. Acesso em: 10 set. 2017.

SARLET, Ingo Wolfgang. Notas sobre a assim designada proibição de retrocesso social no constitucionalismo latino-americano. Revista do TST, Brasília, v. 75, n. 3, p. 116-149, jul/set 2009. Disponível em:

<http://www.abdpc.com.br/admin/midias/anexos/1440694885.pdf>. Acesso em: 26 set. 2017.

SARLET, Ingo Wolfgang; SOARES, Flaviana Rampazzo. Reflexões sobre a dignidade da pessoa humana como fundamento de postulações indenizatórias no direito do trabalho. Civilistica.com - Revista Eletrônica de Direito Civil, v. 6, p. 1$34,2017$. 
SEPARATE opinion of vice-president weeramantry. Disponível em: <http://www.icjcij.org/files/case-related/92/092-19970925-JUD-01-03-EN.pdf>. Acesso em: 17 out. 2017.

SILVA, José Afonso da. Curso de direito constitucional positivo. 34. ed. rev e atual. São Paulo: Malheiros, 2011.

SILVEIRA, Clóvis Eduardo Malinverni. Risco ecológico abusivo: a tutela do patrimônio ambiental nos processos coletivos em face do risco socialmente intolerável. Caxias do Sul: EDUCS, 2014.

SOUZA, Leonardo da Rocha de. Democracia Deliberativa e Justiça Ambiental. Revista Internacional de Direito Ambiental, v. III, n. 8, p. 187-204, 2014.

STEIGLEDER, Annelise Monteiro. Responsabilidade civil ambiental: as dimensões do dano ambiental no direito brasileiro. Porto Alegre: Livraria do Advogado, 2004.

STEINMETZ, Wilson. A vinculação dos particulares a direitos fundamentais. São Paulo: Malheiros, 2004.

UNITED NATIONS OFFICE FOR DISASTER RISK REDUCTION. Terminology. Disponível em: <http://www.unisdr.org/we/inform/terminology>. Acesso em: 04 out. 2017. 